\title{
WestVirginiaUniversity
}

THE RESEARCH REPOSITORY @ WVU

Graduate Theses, Dissertations, and Problem Reports

2017

\section{Whole-Farm Phosphorus Management in West Virginia Beef Cattle Operations}

Justin Brackenrich

Follow this and additional works at: https://researchrepository.wvu.edu/etd

\section{Recommended Citation}

Brackenrich, Justin, "Whole-Farm Phosphorus Management in West Virginia Beef Cattle Operations" (2017). Graduate Theses, Dissertations, and Problem Reports. 5250.

https://researchrepository.wvu.edu/etd/5250

This Thesis is protected by copyright and/or related rights. It has been brought to you by the The Research Repository @ WVU with permission from the rights-holder(s). You are free to use this Thesis in any way that is permitted by the copyright and related rights legislation that applies to your use. For other uses you must obtain permission from the rights-holder(s) directly, unless additional rights are indicated by a Creative Commons license in the record and/ or on the work itself. This Thesis has been accepted for inclusion in WVU Graduate Theses, Dissertations, and Problem Reports collection by an authorized administrator of The Research Repository @ WVU. For more information, please contact researchrepository@mail.wvu.edu. 
Whole-Farm Phosphorus Management in West Virginia Beef Cattle Operations

Justin Brackenrich

Thesis submitted to the

Davis College of Agriculture, Natural Resources, and Design

West Virginia University

in partial fulfillment of the requirements for the degree

Masters of Science in

Agronomy

Louis M. McDonald, Ph.D., Chair

Kevin Shaffer, Ph.D.

Thomas Basden, M.S.

Division of Plant and Soil Sciences

Morgantown, West Virginia

2017

Keywords: Phosphorus, Manure Management, Manure Book Values, Dry-lot Feeding Comprehensive Nutrient Management Plan

Copyright 2017 Justin Brackenrich 


\section{Abstract \\ Whole-Farm Phosphorus Management in West Virginia Beef Cattle Operations}

\section{Justin Brackenrich}

Demand for animal proteins is increasing worldwide, spurring an increase in forage based agricultural production. Forage based agriculture utilizes grass and legume crops from areas which are not suited for row-crop production to feed ruminant animals. These systems provide increased animal proteins to consumer markets, while using minimal amounts of cereal crops that would otherwise be used for human consumption. However, forage based agriculture does not come without a risk of environmental degradation. The US EPA determined that agriculture nonpoint source (NPS) pollution is among the top three causes of phosphorus (P) related surface water impairment and accounts for an estimated 38\% of land degradation worldwide. A lack of conservation planning is the largest cause of $\mathrm{P}$ impairment. In an effort to improve operation management, USDA NRCS is providing cost assistance for comprehensive nutrient management plans (CNMP), heavy use area protection (HUAP), and waste storage facilities (WSF). During the initial planning process for all of these practices, assumptions are made for manure $\mathrm{P}$ concentration based on engineering book values, which were been reported to have errors from 20 to $100 \%$ of analysis values. Current categorizations are based either on herd size or gross farm profit rather than distinguishing management characteristics. A new categorization system has been developed using dry-lot feeding as the distinguishing characteristic. Twelve cow-calf operations in West Virginia, with 16 different WSFs, collectively, were sampled. Four of the 12 operations did not dry-lot feed and were considered to be basic operations; all others were considered complex. To determine if these categories were different, a nutrient mass balance (NMB) was calculated for five of the operations. Basic operations $(n=3)$ had a mean phosphorus use efficiency of $0.02 \mathrm{~kg} \mathrm{P} / \mathrm{kg}$ animal produced, while complex operations $(\mathrm{n}=2)$ had a mean use efficiency of $0.11 \mathrm{~kg} \mathrm{P} / \mathrm{kg}$ animal produced. Based on this new categorization system, manure $\mathrm{P}$ book value and manure $\mathrm{P}$ analysis were compared. For basic operations $(\mathrm{n}=4)$ mean book value manure P concentration was $0.74 \mathrm{~kg}$ P/MT, was statistically different $(\mathrm{p}<0.01)$ than the actual mean analysis of $1.19 \mathrm{~kg}$ P/MT, a difference of $61 \%$. Complex operations $(\mathrm{n}=12)$ mean book value $\mathrm{P}$ concentration was $0.78 \mathrm{~kg} \mathrm{P} / \mathrm{MT}$, also different from the actual mean analysis $(\mathrm{p}<0.01)$ of $1.95 \mathrm{~kg}$ P/MT, a difference of $145 \%$. It is suggested that future HUAP and WSF structures be sized based on the proposed categorization method and resulted manure P concentrations. 


\section{Acknowledgements}

Everyone gets many blessings in their lifetime and I can’t help but feel like I get more than most. My first blessing is my love for agriculture. To me, agriculture is a series of impossible task, faced by underappreciated people, and against all odds they find a way to persevere. I always knew I wanted to a part of agriculture, but also I wanted to make a difference.

Two and a half years ago I received another one of my blessings when Dr. Louis M. McDonald accepted me as one of his graduate students. This will forever be one of the most paramount days of my life. He knew little more about me than what was on paper, but somehow he saw potential and for that I will always be grateful. He had the knowledge to give me direction through my research, but also the wisdom to give me room to make mistakes. As my advisor he not only made me a better student, but a better man. You have my respect and my gratitude.

Another blessing was when Dr. McDonald placed me on a project working with Mr. Tom Basden, Dr. Kevin Shaffer, and WV USDA NRCS staff. In the beginning I was overwhelmed and frustrated, but later I discovered this was also a blessing. Tom Basden has given more practical field knowledge than I thought possible. With all of his knowledge and experience, he still listened to my ideas, good or bad. I did not work as closely with Dr. Shaffer, but I was lucky to have someone as willing as he was to talk about anything livestock. West Virginia USDA NRCS staff were always pleasant and helpful, even when I was making more work for them. They selected my study farms and I could have never asked for a better group. I will never have the pleasure of working with a more kind and progressive group, but above all else, they were willing to listen to a young man that knew a little bit of nothing.

Last but not least, is the blessing of my family and friends. They were there for small things like talking out frustrations, to large things like bank rolling travel to conferences. I will always try to support my children and nieces/nephews as my family supported me. I want to thank Caitlyn for always being there, even when I was stressed and grouchy, it will pay off soon. Finally, my friends, who always asked how things were going, even though you had no clue what I was talking about when I answered. It felt good to be the smartest guy in the room when I was with them. 


\section{Table of Contents}

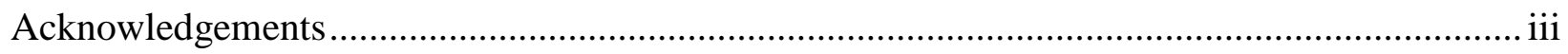

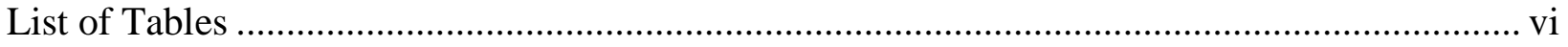

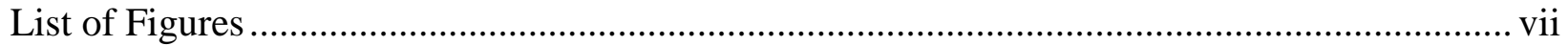

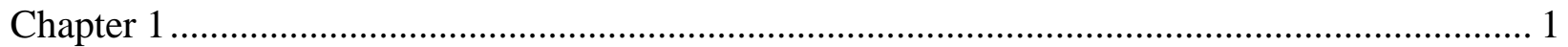

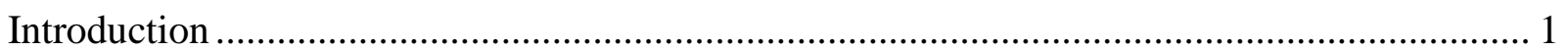

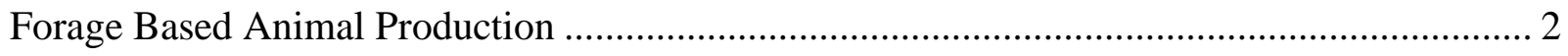

Environmental Degradation and Risk Associated with Forage Based Production .................... 3

Decreasing Environmental Risk and Increasing Sustainability ........................................... 5

Providing More Accurate Recommendations .................................................................. 9

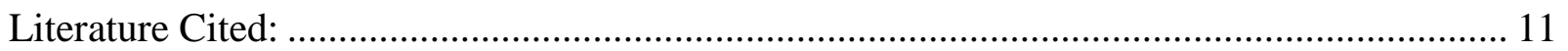

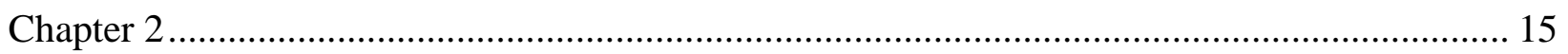

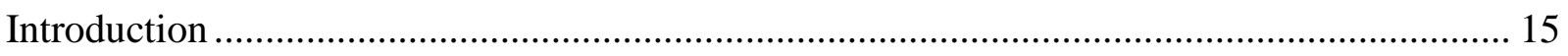

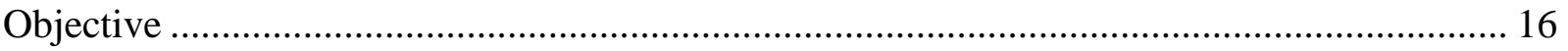

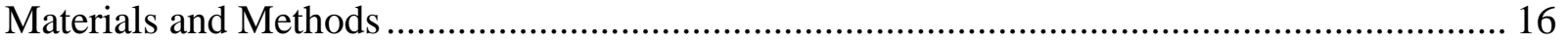

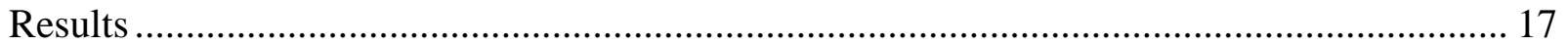

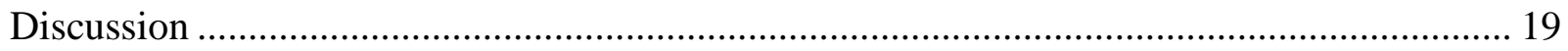

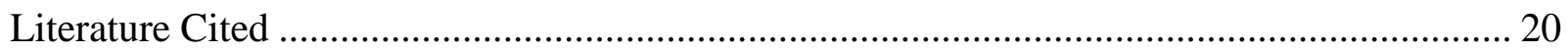

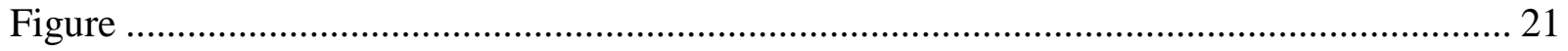

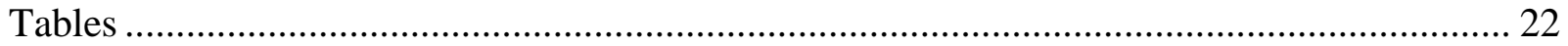

Chapter 3

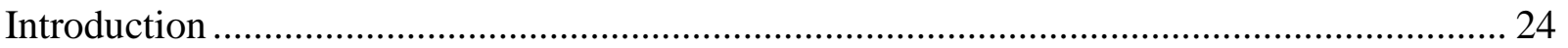

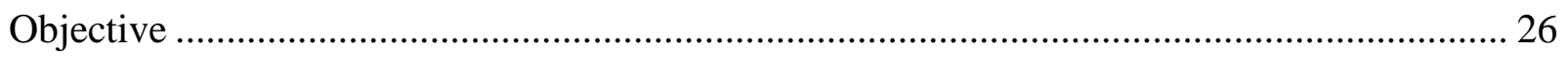

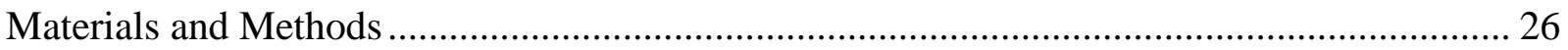

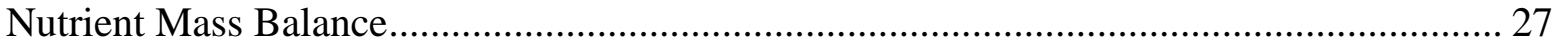

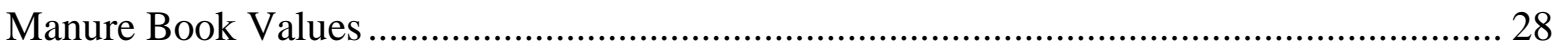

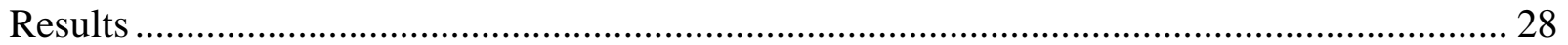

Nutrient Mass Balance......................................................................................... 28

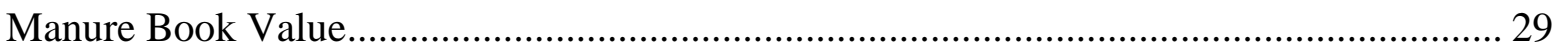

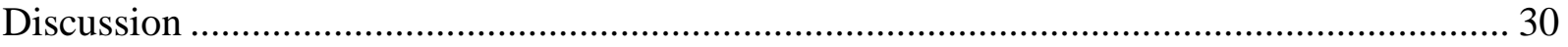

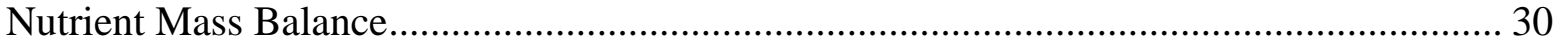

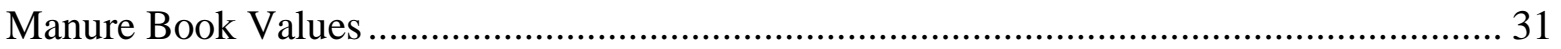




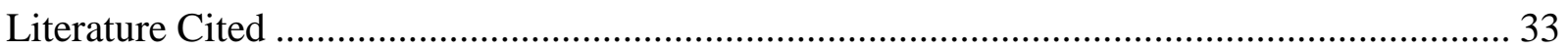

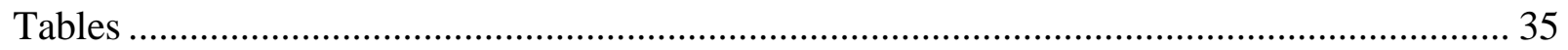

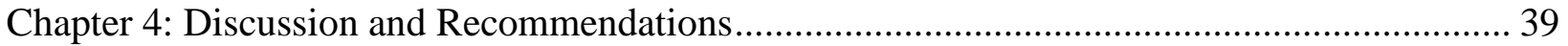

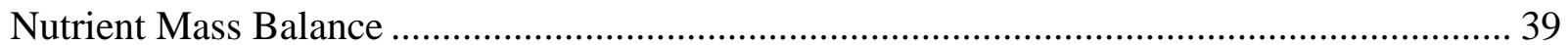

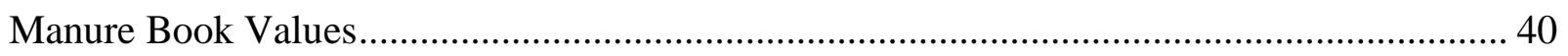

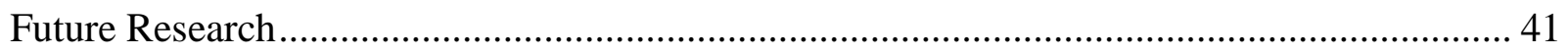

Improved Recommendations for Future CNMPs..................................................................... 42

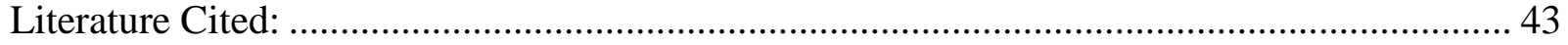




\section{List of Tables}

Table Number

Title

Page

2.1 Descriptive statistics for farm characteristics of twelve beef cattle operations in West Virginia......................................

2.2 Descriptive statistics for farm characteristics of five basic and seven complex beef cattle operations in West Virginia............................

3.1 Farm characteristics used to calculate a nutrient mass balance for five West Virginia beef cattle farms....................................

3.2 Calculated P imports and exported for five West Virginia beef cattle farms.

3.3 Descriptive statistics for farm characteristics of twelve beef cattle four basic operations, and eight complex operations in West Virginia..........

3.4 Manure phosphorus book value and analysis comparison for sixteen samples from four basic operations and twelve complex operations...... 


\section{List of Figures}

Figure Number

Title

Page

1.1 Components of a dairy farm nutrient mass balance.................... 8

2.1 West Virginia's location in the United States and the approximate location of farms sampled in this study............................ 21 


\section{Chapter 1}

\section{Introduction}

Demand for agricultural production has increased globally, while available agricultural land has decreased because of an increasing world population, urban sprawl, and land degradation. World land data estimates from 1960 to 2012, indicate that arable land was reduced by $54 \%$, or 0.27 hectares per capita, while agricultural production continued to meet consumer demand (Pimentel and Wilson, 2004). Maintained production was achieved through higher inputs like nutrients, water, and pesticides; increased breeding efforts; and “Green Revolution” technologies (Tilman et al., 2002).

Global agricultural production is concentrated in four areas, the United States, Brazil, the European Union, and China (CME Group, 2010). High levels of production in these areas has also led to some of the most drastically impaired waters in the world (Carpenter et al., 1998). Sixty percent of the urban ground water in China was determined to be non-potable, which is attributed in large part to agricultural pollution (Jin and Young, 2001). China's agricultural production has increased in the last decades, increasing its contribution to pollution (Jin and Young, 2001). The increase in agriculturally related pollution is a consiquesce of China being among the top ten nations in the use of commercial fertilizer and livestock manure (Jin and Young, 2001; Li et al., 2015). As commercial fertilizer prices increase, animal manures can be a cost effective way to maintain high crop productivity (Sharpley et al., 2006). As a byproduct of animal production operations, manure has value as a nutrient source. According to Eghball and Power (1994), phosphorus (P) in beef manure in the United States was worth $\$ 180$ million when compared to the price commercial P.

Some estimates predict that by 2050 animal production will double on a global scale, while land area involved in animal production will decrease (Capper et al., 2013). Currently 30\% of the Earth's surface is directly or indirectly linked to the production of animal proteins (Ilea, 2009). Confined animal feeding operations are used to concentrate animals in a centralized location, allowing for increased production and decreased shipping costs of both feeds and meat products (Owens, 2014). Because of this influx, animal agricultural production is among the top three largest contributors to environmental issues, making sustainability of animal production questionable (Ilea, 2009). 
Agricultural sustainability is defined as the ability for a system to use practices which allow for the current and future demands to be met, while minimizing degradation to land, ecosystems, and the environment (Tilman et. al., 2002). Another view of sustainability is that production for this generation will not hinder production for the next (Chaudhry, 2008). Phosphorus sustainability is especially difficult due to its importance in plant and animal development, and its environmental risk and mobility through water (Sharpley et. al., 2006).

Phosphorus is one of 16 essential elements required by plants for growth and development. Phosphorous is used in a variety of roles within plants including as a component of nucleic acids, which regulate protein synthesis, cellular division, development of new tissue, winter hardiness, and root tillering (Vance et al., 2003). A large portion of the soil P is unavailable to plants; soil $\mathrm{P}$ can be up to 2,000x higher than plant tissue $\mathrm{P}$, making availability a determining factor for plant growth (Vance et al., 2003; Shenoy and Kalagudi, 2005). Phosphorus is applied to most agricultural land on a yearly basis, steadily increasing concentrations in soils (Vance et al., 2003). Twenty percent or less of soil bound and applied P is removed over periods of vegetative growth and removal. Residual P forms surface complexes with soil minerals and secondary P minerals that result in "P loaded soils" (Vance et al., 2003). Processes of wind and water erosion increase the probability of P loaded soils reaching surface or ground water as a result of seedbed preparation or weed control, over grazing during periods of high water tables and rain, or misapplied manures due to inaccurate recommendations.

\section{Forage Based Animal Production}

Forage-based animal agriculture has the potential to meet the increased demand for animal products because it can be profitable on land that is not suitable for row-crop production. Forage based systems utilize animals as a means of harvest and provide a predominantly perennial grass diet to ruminants (Capper et al., 2013). Production of animals can be done with little or no cereal grains, which could be used by humans directly (Chaudhry, 2008). Properly managed forage based systems can increase production and profitability with few negative environmental impacts, while utilizing areas which would not otherwise provide a direct food source for humans (Capper et al., 2013). In 2012, an estimated 26\% of the world was covered by 60 grasslands, which is a 2\% increase from 2009 (Capper et al., 2013; USDA Census of Agriculture. 2012). By grazing ruminant animals, forages can be collected and utilized with a 
lower environmental impact that would be associated with tillage, planting, and removal of row crops (Capper et al., 2013). Under proper management of pasture rotation, pasture reseeding, and soil fertility practices, pasture lands can be considered the most cost effective and sustainable systems in animal agriculture (Chaudhry, 2008). By developing pastures which are weed free, productive, adaptable, and biologically diverse, not only can a cleaner environment can be achieved but also a better meat product (Chaudhry, 2008).

Appalachia is a prime area to benefit from increased demand for beef. The hill lands of Appalachia in WV and VA have an estimated 1.7 million acres of pasture (Scagia et al., 2008). This temperate zone can produce grass in pasture almost 12 months of the year when properly managed with cool-season grasses and legumes (Scagia et al., 2008). Scagia et al. (2008) found that with the proper management of forage and pasture, stockpiling of grass into the winter can reduce mechanical practices. Rotational grazing and paddock systems in the Shenandoah Valley of VA were studied for their effect on animal production (Scagia et al., 2008). They determined

75 that cows could maintain body weight, soundness, and found no reduction in pregnancy percent. Production on these systems can be profitable, however it does come with risk when proper recommendations are not made.

\section{Environmental Degradation and Risk Associated with Forage Based Production}

Environmental and sustainability concerns of overutilization of pasture and improper feeding strategies, among others, are also associated with forage based animal agriculture. Overutilization of pastures is a worldwide problem, causing an estimated 35.8\% of total agricultural degradation (Radácsi, 2005). Nonpoint source (NPS) pollution is another consequence of mismanaged forage-based systems. It is defined by the presence of a pollutant to a water source without specific outlet or drain (US EPA, 2011). Phosphorus runoff has a direct link to surface water impairment, and eutrophication of some of the world's largest watersheds and drainage basins (Ulén et al., 2007). Current water P pollution levels may have already surpassed sustainable limits, with a projected rise of 40 million metric tons of agriculturally applied P in the next 35 years (Ulén et al., 2007). The most recent data from the EPA suggests that agriculture is currently contributing to impairment of over 227,000 km-1 of rivers and streams, an increase from the previous assessment and publications (US EPA, 2011). 
Overutilization occurs most often when animal stocking rates exceed vegetative production rates (Radácsi, 2005). Overutilization has negative effects on vegetative properties, as well as soil physical properties (Radácsi, 2005). It has been suggested that over-utilizing forages during the production period effects plant growth three times more than when during the dormant period, resulting in key species reduction, decreased plant density and diversity, all of which are essential to productive pastures and sustainability (Radácsi, 2005). Soil physical properties can also be effected by overutilization, contributing to runoff, compaction, and soil erosion. As livestock continue to apply pressure to soils that lack vegetative cover, high bulk density and low structural stability become prevalent (Radácsi, 2005). These properties effect water infiltration and surface runoff, which directly affect erosion rates (Radácsi, 2005).

A study conducted in the European Union found that from the 1930s to the 1990s, soil P concentrations rose due to increased livestock densities and commercial fertilizer use (Ulén et al., 2007). The study found that areas with intensive livestock systems in Norway and the UK were receiving a surplus of $20 \mathrm{~kg}$ /ha/year soil P (Ulén et al., 2007). Norway is still increasing soil surplus P, while the UK is currently in a decline (Ulén et al., 2007). This decline is due to more intensive cropping with higher yields, which removes more soil $\mathrm{P}$ and regulations on stocking density, manure application rate and timing, and fertilization practices being based on soil test P (Ulén et al., 2007). They concluded that in forage based systems stocking density was the second largest cause of unsustainable farming (Ulén et al., 2007)

Another type of NPS is concentrated animal feeding operations. In West Virginia concentrated animal feeding occurs most often as winter feeding of livestock. Winter feeding of livestock also risks degradation and threatens sustainability in forage based systems. During periods of low pasture production, dried grass hay, and grass silage are a typical feed source for ruminant animals (NADIS, 2013). Hay can be fed in the field to livestock either in a ring feeder, a wagon feeder, or rolling large round bales down long sloping areas. When outside feeding of hay occurs under mismanaged conditions concentrated animals and wet ground result in a large amount of mud mixed with feces and urine (NADIS, 2013). Not only can this cause production losses and animal mortality, but it creates an area with high environmental risk (NADIS, 2013). 120 As livestock continue to concentrate, surface vegetation is removed and destroyed, compaction and mixing of soil horizons, and localized nutrient rich "hot spots” occur (NADIS, 2013). 
Continued periods of excessive moisture will cause nutrient rich effluent to flow from these sites as surface water or leach downward as ground water (NADIS, 2013).

\section{Decreasing Environmental Risk and Increasing Sustainability}

It is accepted that the leading cause of agriculture NPS nutrient losses is the lack of conservation planning on agricultural land (US EPA, 2011). Decreasing NPS and degradation associated with farming by focusing on resource concerns is a primary objective of USDA NRCS. The goals are to: reduce soil loss, solve problems with soil, water, air, and agricultural waste; reduce issues associated with increased surface flow or drought; and assisting in facilitating changes to help the land (USDA NRCS, 2012b). A major focus is the implementation of best management practices (BMPs). Best management practices are any practice applied to a farm to reduce and limit environmental risk (Sharpley et al., 2006). Single BMPs rarely make a large enough difference to reduce environmental degradation; therefore, BMPs are often applied

135 in groups which have similar benefits and function together (Sharpley et al., 2006). Important BMPs for forage based livestock producers are conservation planning, heavy use area protection, waste storage facilities, and feed management.

When implementing BMPs, they are often established in order from the broadest, blanketing practices, narrowing in focus to more management intensive practices. The first BMP implemented is typically conservation planning, which is a record of decisions and information used to manage land, meeting the criteria to reduce one or more resource concerns (USDA NRCS, 2013). One primary type of conservation planning is a Comprehensive Nutrient Management Plan (CNMP) (USDA NRCS, 2013). Comprehensive nutrient management plans are currently serving a dual purpose, conservation plans unique to a specific animal livestock operation and as a pre-development tool for waste management facilities (USDA NRCS, 2013). They address the primary components of agricultural NPS pollution: type, timing, and rate of fertilization; estimated volume of stored animal manure; and soil erosion (EPA, 2011).

The first purpose of animal waste management and record of decisions is designed to use farm specific strategies, animal and crop production goals, and agronomic data to develop a long-term plan for nutrient applications (USDA NRCS, 2013; EPA, 2011). When these plans are implemented they result in reduced environmental impact. Applications of nutrients are planned based on removal and needs of crops, and soil test levels for P. If a nutrient application is not 
needed, manure is applied elsewhere on the farm, saving money and nutrients. Historically collected manure has been applied with little or no testing and on the field with shortest travel time from the storage facility (Eigenberg et al., 1998). Generally, beef manure is not considered to have enough nutrient value to export, or to move to longer distances from the WSF (Eigenberg et al., 1998). Since manure contains forage based pass through $P$ and pass through $P$ from grain or other supplements, manure can range from 4:1 to 5:1 N to P ratio, resulting in a surplus of soil P when applied to meet crop nitrogen need (Eigenberg et al., 1998). This means that if beef manure is applied at a crop recommended nitrogen rate, $\mathrm{P}$ is being applied at a rate four to five times larger than is necessary. By implementing a CNMP that requires routine collection and testing of soil and manure samples, in combination with a refined feed management program, surplus P imports can be limited, thus reducing excess soil P concentrations and the associated water quality issues.

Comprehensive nutrient management plans are created using computer-based programs to eliminate human error, automate mathematical calculations, and allow the user to see the impact of management changes immediately (Purdue Research Foundation, 2010). Manure Management Planner, or MMP, is a Windows-based system which incorporates farm and state specific data to make accurate plans which can be easily updated throughout time (Hess, 2010). Manure Management Planner incorporates GIS mapping of fields, surface waters, sensitive features, and other desired shapes which are used in record keeping, P Indices, and Revised Universal Soil Loss Equation 2 (RUSLE2) assessments (Purdue Research Foundation, 2010). Revised Universal Soil Loss Equation 2 RUSLE2 is an erosion model which predicts rill and inter-rill erosion (Dabney et al., 2011). It uses slope, soil, vegetative cover, mechanical operations, and other Best Management Practices (BMPs) to estimate erosion over a cropping period (Dabney et al., 2011). In accordance with individual state NRCS 590 standards, manure setback distances can also be applied to maps. Manure Management Planner incorporates RUSLE2 soil loss predictions, and state specific P indices for environmental risk assessment (Purdue Research Foundation, 2010). Once mapping and RUSLE2 predictions are developed, data is imported to MMP where tabs and fillable cells are used to input farm data. Soil test results are a component to the WV $\mathrm{P}$ indices and also generate crop nutrient recommendations. Crop nutrients recommendations are then used along with manure analysis to calculate manure application and commercial fertilizer rates (Purdue Research Foundation, 2010). Other 
components of a CNMP include crop rotations, infield assessments of surface water, slope, conservation practices, and available equipment used for manure applications, livestock groups, and manure collection (Purdue Research Foundation, 2010).

The second purpose is to ensure that once manure is captured in a Heavy Use Area Protection (HUAP) and associated Waste Storage Facility (WSF) it can be recycled appropriately to the available land area. These structures have two objectives: to provide a stable surface for producers to feed livestock and to improve and protect water quality (USDA NRCS, 2015). A HUAP is designed with a WSF which is built simultaneously and used for containing manure until a period suitable for land applications (USDA NRCS, 2012a). Together these two structures allow manure to be collected and applied to more efficiently recycle farm nutrients. USDANRCS is currently designing and providing cost assistance for HUAPs, WSFs, and CNMPs. Heavy Use Area Protection in West Virginia are primarily roofed feeding pads designed to accommodate a specific type and number of livestock based on engineering calculations from the Agricultural Waste Management Field Handbook (USDA NRCS, 2015). The Agricultural Waste Management Field Handbook (AWMFH) serves multiple uses in the planning and development of these structures, one of which is to determine the total roofed area based on animal type, animal weight, type of structure, and duration of confinement (USDA NRCS, 2015). Waste Storage Facilities are sized using AWMFH calculations. Animal type, weight, and herd size are used to calculate manure volume over the period of confinement (USDA NRCS, 2015).

Another technique in managing $\mathrm{P}$ and reducing environmental risk is whole farm nutrient mass balance (NMB). Animal densities are increasing to provide to the increased need for animal proteins, which can increase the amount of nutrients needed on the farm to continue productivity (Eigenberg et al., 1998). By tracking whole farm NMB, the amount of imported P can be compared to the amount of exported P to determine the net P remaining on the farm (Cale et al., 2014; Van Almelo et al., 2016; Eigenberg et al., 1998). USDA NRCS is beginning to see the value of these assessments for long range plans for dairy farms in New York state (Cela et al.,

210 2014). Currently, the majority of work is being addressed toward the dairy industry because they generate large amounts of manure and import large amount of feeds for milk production (Cela et al., 2014).

Whole Farm NMB starts with a list of all imports which include hay, grain, minerals, commercial fertilizers, etc. All import quantities must be known and have a tested $\mathrm{P}$ 
concentration to calculate total imports (Cela et al., 2014). Exports are calculated in the same way, but for exported products like crops, milk, animals, or manures (Figure 1) (Cornell University Cooperative Extension, 2014). Once imports and exports are identified, P is expressed on a basis of animal production or by land use area (Cornell University Cooperative Extension, 2014). The next step is to determine a baseline so that changes in soil $\mathrm{P}$ over time can be determined (Cela et al., 2014). Baselines can either be established for a specific farm to monitor change over time, or on a regional basis to compare operations.

Ocenema et al. (2003) determined that from 1998 to 1999, $17.6 \mathrm{~kg}$ P/ha/year was acceptable for sustainability for dairies. Farms with net P below this benchmark were able to provide crops sufficient $\mathrm{P}$ for maximum potential without risk of increased soil P accumulations.

225 Continued research demonstrated that $8.8 \mathrm{~kg}$ P/ha was a more appropriate benchmark for dairy farms in the Netherlands (Wright and Mallia, 2008). Cela et al. (2014) chose an initial bench mark of $13 \mathrm{~kg}$ P/ha for New York dairies because 75\% of the studied farms were currently accumulating $\mathrm{P}$ at or below this mark. This benchmark was further supported by its similarity to the Netherlands benchmark of $8.8 \mathrm{~kg}$ P/ha, and the European Union imposed limit on dairies in Northern Ireland of $10 \mathrm{~kg}$ P/ha (Cela et al., 2014).

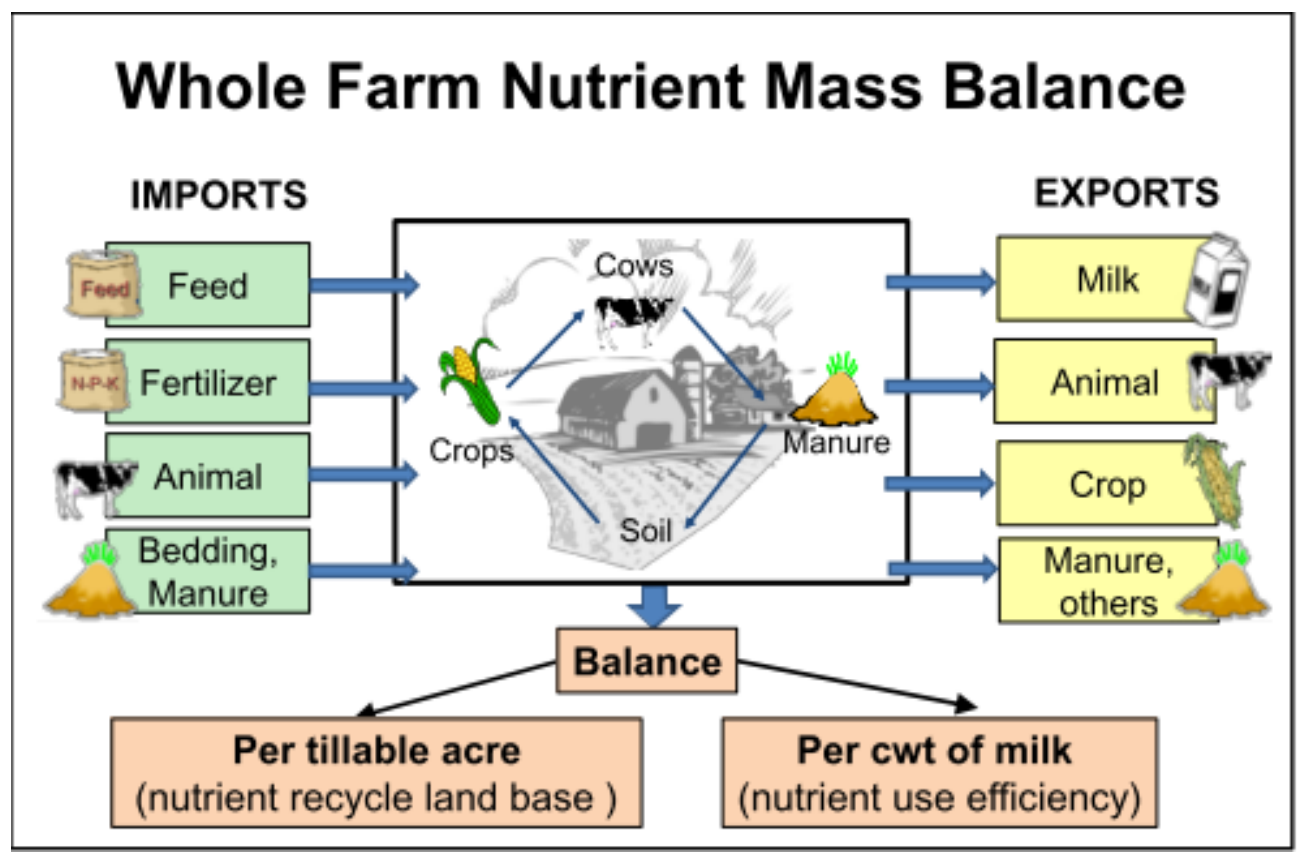

Figure 1.1. Components of a dairy farm nutrient mass balance. (Cornell University Cooperative Extension, 2014) 
Feed management has become a high priority BMP for many animal livestock operations. Feed management is designed to supply animals with the nutrients needed for maintenance, production, and performance, while reducing excess nutrients in animal manure by minimizing over feeding (USDA NRCS, 2006). A major concern of animal production is manure nutrient analysis and manure volume associated with over-feeding (Sharpley et al., 2006). NRCS ARS conducted research on the reduction of agricultural P pollution and strategies to reduce losses through BMPs. One of the suggested methods of reduction was through regulation of $\mathrm{P}$ in ruminant diets (Sharpley et al., 2006). Research suggested that a diet formulated to meet animal requirements can reduce manure P concentration by 10 to 20\% (Sharpley et al., 2006). Feeding P above daily requirements added no growth potential and decreased profit as a result of increased feeding costs (Sharpley et al., 2006). Based on relationships between daily P intake and manure $\mathrm{P}$, a reduction of $0.10 \%$ intake concentration resulted in a 30 to 35\% smaller manure P (Sharpley et al., 2006). When expressed in relation to land area and sustainability, the land area need to recycle $\mathrm{P}$ is reduced from 1.2 area to 0.7 area, if total feed ration $\mathrm{P}$ concentration is reduced from 0.55\% to $0.38 \%$ P (Sharpley et al., 2006). Applying manure from animals fed a ration containing 0.55\% P to 0.7 ha, would result in an estimated 2 ppm per year increase of soil P (Sharpley et al., 2006).

Another benefit of feeding management associated with HUAPs is feed use efficiency. Feeding large round bales without a ring feeder can result in losses of between 12.3 and $43.0 \%$, while feeding within a ring of confined area reduces loss to 4.9 to 5.4\% (Kallenbach, 2000). By

255 reducing feed waste operations would need to feed less which in turn would allow them to export hay decreasing net $\mathrm{P}$ in a NMB.

\section{Providing More Accurate Recommendations}

Improved on-farm P management begins with better, production-system based recommendations. Currently farms in the US are categorized as large, medium, or small. These groupings are based on either economic status or herd size. A study by the USDA National Animal Health Monitoring System, NAHMS, defined small beef cow-calf farms as any farm with less than 100 brood cows (APHIS, 2009), while the USDA's Economic Research Service, ERS, classifies a small farm by a gross cash farm income (GCFI) of less than \$350,000 (Hoope et al., 2016). West Virginia is made up of an estimated 93\% to 97\% small farms when 
categorized by herd size, or GCFI, respectively (APHIS, 2009; Hoope et al., 2016). There may be an opportunity to improve whole-farm P management to minimize the negative impacts of off-farm P movement and increase sustainability and farm economics with a better classification system.

This study has the primary objective of determining if categorization based on either dry-lot feeding, animal feed supplementation, or animal densities will provide more accurate recommendations for P management on forage based animal production systems. Categories will be determined by the characteristic of the sampled operations. After categories are determined, NMB will be used to verify if operations are different. Secondary objectives are: make better recommendations of manure P content and identify areas where future research can be conducted to increase whole farm P management. 


\section{Literature Cited:}

Animal and Plant Health Inspection Service. (2009). NAHMS small livestock farm characteristics. Retrieved from https://www.aphis.usda.gov/animal_health/nahms. (Retrieved 4/4/2017).

Capper, J., Berger, L., Brashears, M., \& Jensen, H. (2013). Animal feed vs. human food: Challenges and opportunities in sustaining animal agriculture toward 2050. Retrieved from http://lib.dr.iastate.edu/econ_reportspapers/16/. (Retrieved 4/4/2017)

Carpenter, S. R., Caraco, N. F., Correll, D. L., Howarth, R. W., Sharpley, A. N., \& Smith, V. H. (1998). Nonpoint pollution of surface waters with phosphorus and nitrogen. Ecological applications, 8(3), 559-568. (Retrieved 4/4/2017).

Cela, S., Ketterings, Q. M., Czymmek, K., Soberon, M., \& Rasmussen, C. (2014). Characterization of nitrogen, phosphorus, and potassium mass balances of dairy farms in New York State. Journal of dairy science, 97(12), 7614-7632. (Retrieved 4/4/2017)

Chaudhry, A. S. (2008). Forage based animal production systems and sustainability, an invited keynote. Revista Brasileira de Zootecnia, 37(SPE), 78-84. doi: 10.1590/S151635982008001300010. (Retrieved 4/4/2017).

CME Group. (2010). Daily livestock report, 8(126). Retrieved from http://www.dailylivestockreport.com/documents/dlr\%206-30-2010.pdf. (Retrieved 4/4/2017).

Cornell University Cooperative Extension. (2014). Nutrient mass balance: fact sheet 25. Retrieved from http://nmsp.cals.cornell.edu/guidelines/factsheets.html. (Retrieved 4/4/2017).

Dabney, S. M., Yoder, D. C., Vieira, D. A., \& Bingner, R. L. (2011). Enhancing RUSLE to include runoff-driven phenomena. Hydrological Processes, 25(9), 1373-1390. (Retrieved 4/4/2017).

Dou, Z., Galligan, D. T., Allshouse, R. D., Toth, J. D., Ramberg, C. F., \& Ferguson, J. D. (2001). Manure sampling for nutrient analysis. Journal of environmental quality, 30(4), 14321437. (Retrieved 4/4/2017).

Eghball, B., \& Power, J. F. (1994). Beef cattle feedlot manure management. Journal of Soil and Water Conservation, 49(2), 113-122. (Retrieved 4/4/2017).

Eigenberg, R. A., Korthals, R. L., Nienaber, J. A., \& Hahn, G. L. (1998). Implementation of a mass balance approach to predicting nutrient fate of manure from beef cattle feedlots. Applied Engineering in Agriculture, 14, 475-484. (Retrieved 4/4/2017). 
Hoppe, R. A., Banker, D. E., \& MacDonald, J. M. (2010). America's diverse family farms. Economic Information Bulletin-USDA Economic Research Service, (67). Retrieved from https://www.cabdirect.org/cabdirect/abstract/20103259789. (Retrieved 4/4/2017).

Ilea, R. C. (2009). Intensive livestock farming: Global trends, increased environmental concerns, and ethical solutions. Journal of Agricultural and Environmental Ethics, 22(2), 153-167. (Retrieved 4/4/2017).

Jin, L., \& Young, W. (2001). Water use in agriculture in China: importance, challenges, and implications for policy. Water policy, 3(3), 215-228. (Retrieved 4/4/2017).

Kallenbach, R. L. (2000). Reducing losses when feeding hay to beef cattle. Extension publications (MU). Retrieved from http://hdl.handle.net/10355/3531. (Retrieved 4/4/2017).

Li, H., Liu, J., Li, G., Shen, J., Bergström, L., \& Zhang, F. (2015). Past, present, and future use of phosphorus in Chinese agriculture and its influence on phosphorus losses. Ambio, 44(2), 274-285. doi: 10.1007/s13280-015-0633-0. (Retrieved 4/4/2017).

Lindley, J. A., Johnson, D. W., \& Clanton, C. J. (1988). Effects of handling and storage systems on manure value. Appl. Eng. Agric, 4(3), 246-252. (Retrieved 4/4/2017).

National Animal Disease Information Service. (2013). Out-wintering of cattle. Retrieved from http://www.nadis.org.uk/bulletins/out-wintering-of-cattle.aspx. (Retrieved 4/4/2017).

Oenema, O., Kros, H., \& de Vries, W. (2003). Approaches and uncertainties in nutrient budgets: implications for nutrient management and environmental policies. European Journal of Agronomy, 20(1), 3-16. (Retrieved 4/4/2017).

Owens, C. (2014). Industrial urbanization. Retrieved from http://www.internationalurbanization.org/uploads/2/3/3/5/23354588/the_environmental_i mpact_of_the_meat_industry.pdf. (Retrieved 4/4/2017).

Pimentel, D., \& Wilson, A. (2004). World population agriculture and malnutrition. World Watch, 22-25. (Retrieved 4/4/2017).

Purdue Research Foundation. (2010). Getting started with manure management planner. Retrieved from http://www.purdue.edu/agsoftware/mmp/MmpGuide.htm. (Retrieved 4/4/2017).

Radácsi, L. C. A. (2005). Overutilization of pastures by livestock. Acta pascuorum (Grassland studies), 3, 29-36. Retrieved from http://gyep.kti.szie.hu/pdf/pdf_46.pdf. (Retrieved 4/4/2017).

Rieck-Hinz, A. M., Miller, G. A., \& Schafer, J. W. (1996). Nutrient content of dairy manure from three handling systems. Journal of production agriculture, 9(1), 82-86. (Retrieved 4/4/2017). 
Scaglia, G., Swecker, W. S., Fontenot, J. P., Fiske, D., Fike, J. H., Abaye, A. O., ... \& Hall, J. B. (2008). Forage systems for cow-calf production in the Appalachian region. Journal of animal science, 86(8), 2032-2042. (Retrieved 4/4/2017).

Sharpley, A. N., Daniel, T., Gibson, G., Bundy, L., Cabrera, M., Sims, T., Stevens, R., Lemunyon, J., Kleinman, P., Parry, R. (2006). Best management practices to minimize agricultural phosphorus impacts on water quality. Retrieved from https://www.ars.usda.gov/research/publications/publication/?seqNo115=145857. (Retrieved 4/4/2017).

Shenoy, V. V., \& Kalagudi, G. M. (2005). Enhancing plant phosphorus use efficiency for sustainable cropping. Biotechnology advances, 23(7), 501-513. (Retrieved 4/4/2017).

Tilman, D., Cassman, K. G., Matson, P. A., Naylor, R., \& Polasky, S. (2002). Agricultural sustainability and intensive production practices. Nature, 418(6898), 671-677. (Retrieved 4/4/2017).

Ulén, B., Bechmann, M., Fölster, J., Jarvie, H. P., \& Tunney, H. (2007). Agriculture as a phosphorus source for eutrophication in the north-west European countries, Norway, Sweden, United Kingdom and Ireland: a review. Soil Use and Management, 23(s1), 5-15. (Retrieved 4/4/2017).

US Environmental Protection Agency. (2011). A national evaluation of the clean water act section 319 program. Retrieved from https://www.epa.gov/sites/production/files/201509/documents/319evaluation.pdf. (Retrieved 4/4/2017).

USDA Census of Agriculture. (2012). United States summary and state data. Retrieved from https://www.agcensus.usda.gov/Publications. (Retrieved 4/4/2017).

USDA Natural Resources Conservation Service. (2006). WV NRCS practice standard: feed management. (Retrieved 4/4/2017).

USDA Natural Resources Conservation Service. (2012b). Conservation technical assistance. Retrieved from https://www.nrcs.usda.gov/wps/portal/nrcs/main/national/programs/technical/cta. (Retrieved 4/4/2017).

USDA Natural Resources Conservation Service. (2013). WV NRCS practice standard:nutrient management. (Retrieved 4/4/2017).

USDA Natural Resources Conservation Service. (2015). WV NRCS practice standard: heavy use area protection. (Retrieved 4/4/2017).

Van Almelo, J., Ketterings, Q.M., and Cela, S. (2016). Integrating record keeping with whole farm futrient mass balance: a case study. Journal of Agricultural Science, 8(6):22. (Retrieved 4/4/2017). 
Vance, C. P., Uhde-Stone, C., \& Allan, D. L. (2003). Phosphorus acquisition and use: critical adaptations by plants for securing a nonrenewable resource. New Phytologist, 157(3), 423-447. (Retrieved 4/4/2017).

Wright, S., \& Mallia, C. (2008). The Dutch approach to the implementation of the nitrate directive: Explaining the inevitability of its failure. The Journal of Transdisciplinary Environmental Studies, 7(2), 1-16. (Retrieved 4/4/2017). 


\section{Chapter 2: Summary Characteristics of West Virginia Beef Cattle farms with Heavy Use Area Protection}

\section{Introduction}

West Virginia is made up of an estimated 93\% to 97\% small farms when categorized by herd size or gross cash farm income, respectively (APHIS, 2009; Hoope et al., 2016). These methods of categorization are too broad to accurately categorize small herd beef cow production systems. Distinct differences in manure handling practices and manure characteristics are present with different management systems which influences application rate. In cases where farms do not use confinement, cows and calves spend a majority of their time in pasture manure is returned directly as a nutrient source. This will result in less manure and manure bound nutrients in storage at the end of the winter period. If a farm uses confinement, manure volume and manure bound nutrients will be in a larger quantity. Confinement in this context refers to dry lot feeding of livestock as part of a prescribed animal management process. Dry lot feeding is a practice in which calves are fed supplements and grain to increase growth before sale. Dry lot feeding encourages animals to eat from feed bunks and become accustomed to eating grain based diets rather than hay and pasture.

Dry lot feeding of calves for enhanced growth and performance is a common management practice for West Virginia beef cattle operations looking to improve calf crop profitability. To stimulate growth, weaned calves are confined to a winter feeding area and fed a nutrient dense, high protein diet of grain and mineral supplements. On many small operations diets are not based on a feed management plan, but rather a desired weight, on a group basis, i.e. $45 \mathrm{~kg}$ for the herd per day. A feed management plan would adjust the feeding rate to the proper amount of feed for a specific physiological stage of a specific group of animals. Without feeding plans, concentrate feeds are based on animal weight but often do not change with animal growth. Animals are allowed to leisure eat and results in a large amount of pass through $\mathrm{P}$ in the manure because of over feeding. Over feeding not only causes an increased amount of manure bound P, but an increased volume of manure for later land application.

Imported manure such as confinement poultry litter used as a fertility amendment is a common practice in grass based operations in WV and should be considered as a distinguishing characteristic. In areas of WV where commercial poultry production is prevalent, large quantities of P can quickly be imported. Often, poultry litter is used to meet cropping needs for nitrogen or 
potassium but not $\mathrm{P}$. This results in a large amount of residual $\mathrm{P}$ accumulating in pasture and hay fields which have little to no removal throughout the cropping year. Litter is often inexpensive or free in some areas of WV and is applied at a "disposal" rate of up to $85 \mathrm{~kg} \mathrm{P}_{2} \mathrm{O}_{5} /$ ha. Farms can also import commercial fertilizers, but due to the cost of commercial products, they are applied at the recommended rate from a nutrient management plan or strategic soil sampling.

Animal stocking density should also be considered a distinguishing characteristic for operations. Studies show that stocking densities have a relationship on the amount of imported $\mathrm{P}$ within a system (Ulén et al., 2007). As livestock numbers increase, land area productivity must also increase to support it. Animal manures or fertilizers for vegetative productivity and increased grains and supplements for animal growth can increase productivity. If land area and 435 productivity does not increase, feed stuffs must be imported to continue production (Ulén et al., 2007).

\section{Objective}

The objective of the study was to use survey data to categorize small beef cattle farms in West Virginia based on management strategies.

\section{Materials and Methods}

This research was a component of a larger Cooperative Agreement between West Virginia University, WVU-Extension Service and NRCS to develop CNMPs in WV. The Cooperative Agreement placed up to six undergraduate summer interns in NRCS offices in WV to assist with CNMP development. Prior to placement, interns received training from WVU Faculty and Extension Specialists in: proper field sampling techniques for forage, soil, manure; manipulation of basic data on Windows based software like MMP, RUSLE2, ArcMap; and USDA NRCS requirements for CNMPs. Once in place, interns collected data for MMP development which included soil and manure samples, animal head number, type and physiological maturity, manure type (liquid, semi-solid, etc.), generation estimates, storage capacity, vegetation rotations, yield goals, and feed storage methods. The initial focus was on farms that had or were seeking cost-sharing for roofed winter feeding structures. In accordance with the HUAP 561 standard, all operating and planned facilities must have implemented a CNMP that meets the 590 standard. 
USDA NRCS staff initiated contact with cooperating operations in areas where summer interns had been placed. Farms were selected by NRCS staff based on their opinion of the likelihood of cooperation with the study, reliability of data provided, and predetermined project guidelines (Appendix A). NRCS selected farms were assessed by summer interns (Appendix B). Summer interns organized collected data, and final eligibility was determined by a WVU graduate student. If the farm was determined to be eligible, more data was collected using a detailed list (Appendix C). This uniform method for collecting farm specific information was used throughout the research and for the completion of CNMPs for the selected farms. The graduate student and summer interns collected farm information and data during the summer of 2015 and 2016. Categories by which farms were measured were based on examples from Van Almelo et al., 2016. Because calves are the principal export of these operations, they will be assessed on a kg P/ production ha and kg P/ kg animal produced basis. As shown in (Van Almelo et al., 2016), using AU/ area provides results on a production land area basis and $\mathrm{kg}$ P/ kg produced shows feed efficiency.

\section{Results}

Study farms represented two of the four geogrophical regions found in West Virginia; Ohio River Valley ( $n=9$ ) and Potomac Section $(n=3)$ (Figure 3), for a total data set of $n=12$. The mean herd size was 42 mature angus cross brood cattle (Table 2.1) (Raw data in Appendix D). Other characteristics were a mean value of $50 \mathrm{AU}, 48$ production hectares, and 19 spreadable hectares. Production area was determined as any land on the farm used for cropping or as pasture for grazing animals. Spreadable area were determined by GIS mapping and the removel of land area from manure applications based on WV USDA NRCS 590 Standard for Manure Setbacks within the technical notes of the WV USDA NRCS 590 standard (Appendix E). Animal units were based on a $544 \mathrm{~kg}$ mature cow and calves sold at $249 \mathrm{~kg}$.

Yes and no questions from the questionaire were assigned numerical value so comparisons could be made. Answers of yes were given a value of 1 and answers of no were given a value of 0 . The percent shown in these questions is the percent of farms which answered yes. Fifty-eight percent of farms answered yes to dry lot feeding, while only $8 \%$ answered yes to imported manure. All operations in the study grew forage, while 17 and 25 percent imported and exported forage, respectively. Imported forages were classified as any forage that was brought 
onto the operation from an external source, and exported forages were shipped from the farm. Fifty-eight percent of operations imported grains and 17\% grew grains. Imported grains were purchased from local mills and grown grains refered to on farm corn production.

Animal units/ production hectare had a mean value of 1.6 and ranged from 0.7 to 2.8 and AU/spreadable hectare had a mean value of 4.2 and ranged from 1.5 to 10.5. Animal units on a spreadable area basis were higher because all farms had an average of three times more production area than spreadable area.

The majority of feed was pasture and mixed legume-grass hay on all operations. All operate with a HUAP as a roofed winter feeding area, where hay is fed during the wet months of winter and manure is stored until proper field applications can be made. Over $40 \%$ of all farmed land area received manure annually, and all had an animal densities of less than 3 AU/ production hectare. Because 58\% answered yes to dry lot feeding of animals, dry lot feeding was chosen to be the classifying factor between "basic” and “complex” management systems. Dry lot feeding requires grains to be produced or purchased which by default increases the complexity of the operations.

Basic farms have the most basic management for a beef operation. Basic farms $(\mathrm{n}=5)$ had no dry lot feeding (Table 2.2). These farms had a mean value of 29 brood cows with a range from 20 to 43 head and 34 ha of production area with a range from 20 to 60 ha. Calves birthed in fall or spring and are sold at an average weight of $249 \mathrm{~kg}$ (550 lbs.) through conventional methods. These operations supplement a minimal percent of the animals total diet with grain. Forty percent import hay and 80\% import grain. None of these operations grew grain for animal use or export. Basicoperations had a mean AU/ production ha of 1.6 and ranged from 1.0 to 2.2.

Complex farms $(n=8)$ were all other farms in this study. These farms utilized animal dry 510 lot feeding, imported grain and supplements, and imported animal waste as a fertilizer. Herd size had a mean value of 51 with a range form 20 to 100 head and production area of 59 ha with a range from 17 to 104 ha. None of these operations imported forage, however, 29\% exported forage. Forty-three percent imported grain and 29\% grew grain. Animal unit/ production ha had a mean value of 1.6 with a range from 0.7 to $2.8 \mathrm{AU} / \mathrm{ha}$. 


\section{Discussion}

The vast majority of WV beef cattle farms are considered small by conventional standards (herd size and income). The same is likely true of most beef cattle farms in Appalachia. Categorizing farms by management practices is the first step toward improved $\mathrm{P}$ management for beef cattle farms. Based on a survey of NRCS cooperating farms, two management categories were identified. Basic farm systems were the simplest cow-calf operations in that calves were weaned and sold with minimal supplementation. Complex production systems had one or more management pracice that distinguished it from a basic production system The most important of these were dry lot feeding and imported manure. 


\section{Literature Cited}

Animal and Plant Health Inspection Service. (2009). NAHMS small livestock farm characteristics. Retrieved from https://www.aphis.usda.gov/animal_health/nahms. (Retrieved 4/4/2017).

Eigenberg, R. A., Korthals, R. L., Nienaber, J. A., \& Hahn, G. L. (1998). Implementation of a mass balance approach to predicting nutrient fate of manure from beef cattle feedlots. Applied Engineering in Agriculture, 14, 475-484. (Retrieved 4/4/2017).

Hoppe, R. A., Banker, D. E., \& MacDonald, J. M. (2010). America's diverse family farms. Economic Information Bulletin-USDA Economic Research Service, (67). (Retrieved 4/4/2017).

Purdue Research Foundation. (2010). Getting started with manure management planner. Retrieved from http://www.purdue.edu/agsoftware/mmp/MmpGuide.htm. (Retrieved 4/4/2017).

540 Ulén, B., Bechmann, M., Fölster, J., Jarvie, H. P., \& Tunney, H. (2007). Agriculture as a phosphorus source for eutrophication in the north-west European countries, Norway, Sweden, United Kingdom and Ireland: a review. Soil Use and Management, 23(s1), 5-15. (Retrieved 4/4/2017).

USDA Census of Agriculture. (2012). United States summary and state data. Retrieved from https://www.agcensus.usda.gov/Publications. (Retrieved 4/4/2017).

USDA National Agricultural Statistics Service. (2016). West Virginia state agricultural overview. Retrieved from https://www.nass.usda.gov/Quick_Stats/Ag_Overview/stateOverview.php?state=west\%2 0virginia. (Retrieved 4/4/2017).

Van Almelo, J., Ketterings, Q.M., and Cela, S. (2016). Integrating record keeping with whole farm futrient mass balance: a case study. Journal of Agricultural Science, 8(6):22. (Retrieved 4/4/2017). 


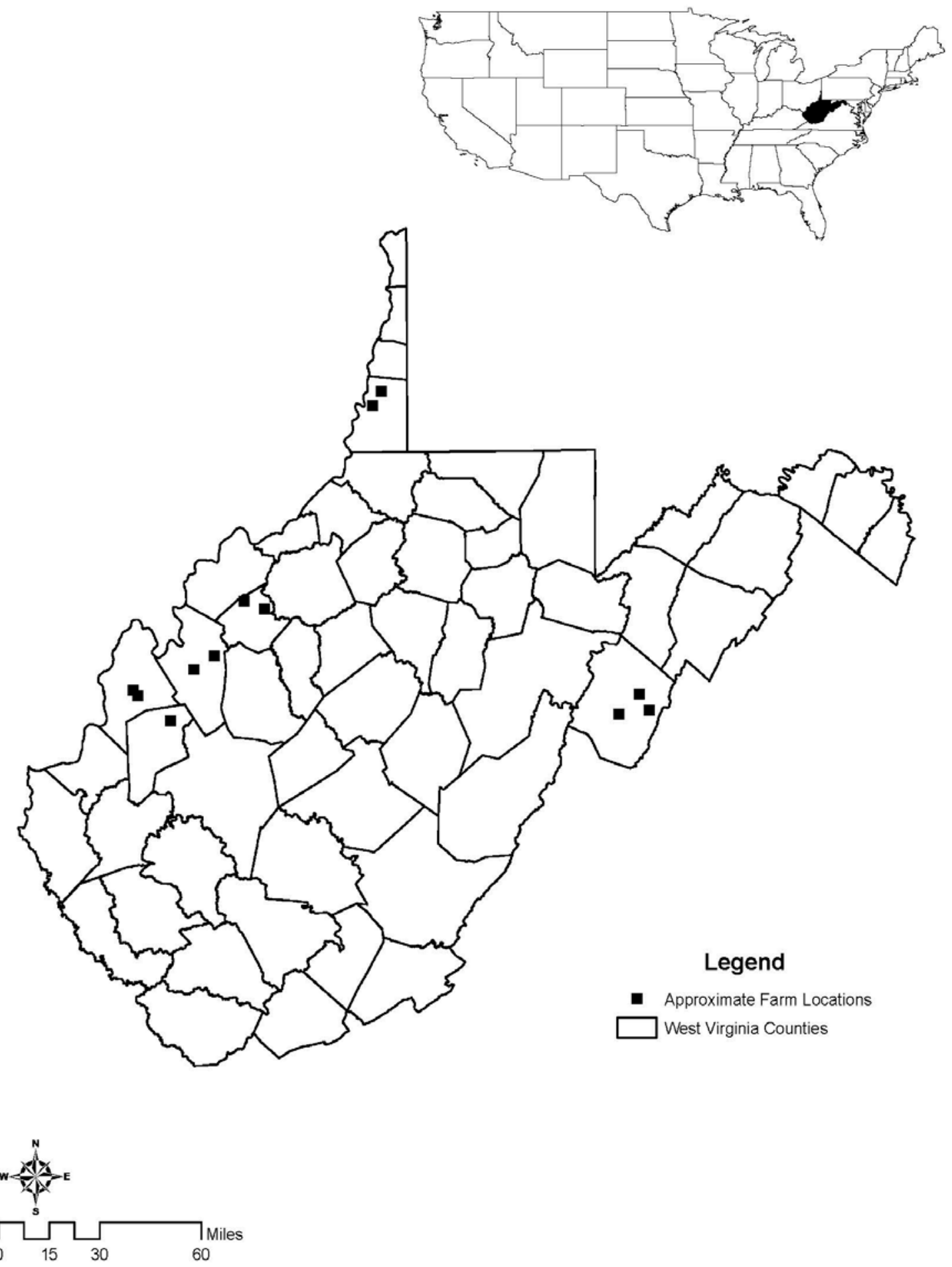

Figure 2.1. West Virginia's location in the United States and the approximate location of farms sampled in this study. 


\section{Tables}

Table 2.1. Descriptive statistics for farm characteristics of twelve beef cattle operations in West Virginia.

\begin{tabular}{|c|c|c|c|c|}
\hline Characteristics & Mean & SD & Minimum & Maximum \\
\hline \multicolumn{5}{|l|}{ Farm Size } \\
\hline Herd Size & 42 & 23 & 20 & 100 \\
\hline Animal Units ${ }^{3}$ & 50 & 8 & 24 & 120 \\
\hline Production ha ${ }^{1}$ & 48 & 30 & 17 & 104 \\
\hline Spreadable ha ${ }^{2}$ & 19 & 10 & 5 & 41 \\
\hline \multicolumn{5}{|l|}{ Herd Management } \\
\hline Dry Lot Feeding* & $58 \%$ & & & \\
\hline Animals Sold & 38 & 23 & 16 & 95 \\
\hline \multicolumn{5}{|l|}{ Crop Management } \\
\hline Forage Grown* & $100 \%$ & & & \\
\hline Forage Imported* & $17 \%$ & & & \\
\hline Forage Exported* & $25 \%$ & & & \\
\hline Grain Grown* & $17 \%$ & & & \\
\hline Grain Imported* & $58 \%$ & & & \\
\hline \multicolumn{5}{|l|}{ Density } \\
\hline AU/ production ha & 1.6 & 0.6 & 0.7 & 2.8 \\
\hline AU/ spreadable ha & 4.2 & 2.4 & 1.5 & 10.5 \\
\hline $\begin{array}{l}1=\text { Total area on which } \\
2=\text { Total area on which } \\
3=\text { Animal Units reflect } \\
* \text { Signifies an average } \\
\text { Yes to the question }=\end{array}$ & $\begin{array}{l}\text { vestock } \\
\text { ollected } \\
\text { total AL } \\
\text { farms p } \\
\text { and No }\end{array}$ & $\begin{array}{l}\text { aze } \\
\text { e is a } \\
\text { s and } \\
\text { ating }\end{array}$ & ecific man & \\
\hline
\end{tabular}


Table 2.2. Descriptive statistics for farm characteristics of five basic and seven complex beef cattle operations in West Virginia.

\begin{tabular}{|c|c|c|c|c|c|c|c|c|}
\hline \multirow[b]{2}{*}{ Characteristics } & \multicolumn{4}{|c|}{ Basic $(n=5)$} & \multicolumn{4}{|c|}{ Complex $(\mathrm{n}=7)$} \\
\hline & Mean & SD & Minimum & Maximum & Mean & SD & Minimum & Maximum \\
\hline \multicolumn{9}{|l|}{ Farm Size } \\
\hline Herd Size & 29 & 9 & 20 & 43 & 51 & 27 & 20 & 100 \\
\hline Animal Units & 48 & 14 & 32 & 71 & 85 & 46 & 32 & 168 \\
\hline Production ha & 34 & 18 & 20 & 60 & 59 & 34 & 17 & 104 \\
\hline Spreadable ha & 17 & 8 & 10 & 30 & 20 & 11 & 5 & 41 \\
\hline \multicolumn{9}{|l|}{ Herd Management } \\
\hline Dry Lot Feeding* & $0 \%$ & & & & $100 \%$ & & & \\
\hline Animals Sold & 25 & 8 & 16 & 38 & 47 & 27 & 16 & 95 \\
\hline \multicolumn{9}{|l|}{ Crop Management } \\
\hline Forage Grown* & $100 \%$ & & & & $100 \%$ & & & \\
\hline Forage Imported* & $40 \%$ & & & & $0 \%$ & & & \\
\hline Forage Exported* & $20 \%$ & & & & $29 \%$ & & & \\
\hline Grain Grown* & $0 \%$ & & & & $29 \%$ & & & \\
\hline Grain Imported* & $80 \%$ & & & & $43 \%$ & & & \\
\hline \multicolumn{9}{|l|}{ Density } \\
\hline AU/ production ha & 1.6 & 0.5 & 1.0 & 2.2 & 1.6 & 0.7 & 0.7 & 2.8 \\
\hline AU/ spreadable ha & 3.3 & 1.7 & 1.5 & 5.6 & 4.8 & 2.7 & 2.1 & 10.5 \\
\hline
\end{tabular}

* Signifies an average of farms participating in the specific management.

Yes to the question $=1$ and $\mathrm{No}=0$ 


\section{Chapter 3: Whole Farm Nutrient Mass Balance and Implications for Sustainable Phosphorus Management}

\section{Introduction}

Increased demand for animal production on forage systems has led to a need for increased production. This need can be met by increasing soil fertility of production areas, increasing the amount livestock feed provided or starting new animal production operations (Cela et al., 2014). All of these options can result in potential environmental risk or land degradation, but can be very efficient when managed with the proper guidelines and recommendations. Increased use of fertilizers or imported animal manures as fertilizers have the potential to increase soil $\mathrm{P}$ concentrations above what is needed by plants in forage based systems. Also, importing feeds and minerals can increase the amount of P in manure captured during winter feeding. Lastly, without proper recommendations for new operations and proper manure management, environmental risk is almost certain to occur. With farms categorized based on management practices, better recommendations for each of these scenarios is possible.

The first concern is the importation of $\mathrm{P}$ in mass quantities as either feed, commercial fertilizers, or animal manures. One way to monitor the rate at which operations increase or decrease $\mathrm{P}$ is through nutrient mass balance (NMB) (Cela et al., 2014). Whole farm NMB is an accounting system which shows breaks in nutrient cycling and areas where utilization efficiency is poor (Cornell University Cooperative Extension, 2014). Numerous studies have been conducted on dairy farms across the United States and the world resulting in P sustainability benchmarks from $8 \mathrm{~kg} \mathrm{P} / \mathrm{ha}$ to $13.3 \mathrm{~kg} \mathrm{P} / \mathrm{ha}$. The term sustainability benchmark is used to express a relationship between net P (imports-exports) and a product or land area (Cela et al., 2014). Benchmarks allow an operation’s nutrient recycling efficiency to be evaluated for sustainability with a single year of data (Cela et al. 2014; Van Almelo et al., 2016; Wright and Mallia, 2008). Cow-calf operations tend to have large quantities of imported nutrients in feeds

585 and fertilizers, but have low exported amounts because the main export is animal protein. This larger import to export ratio can lead to sustainability issues when nutrients are not monitored. An understanding of NMB for the categories established in Chapter 2 could provide farmers and government agencies opportunities to reduce unnecessary imports and monitor the fate of $\mathrm{P}$ within the farm. 
A study by Sharpley et al. (1998) on the mass balance and fate of nutrients in beef stocker cattle feed lots addressed this challenge. Their purpose was to prepare a model which would allow for the integration of management and P destinations across farms (Eigenberg et al., 1998). They noted that manure was primarily deposited on the closest fields to the areas of confinement (Eigenberg et al., 1998). Farmers and applicators of manure felt that the manure did not have enough nutrient value to justify moving it across the farm or trying to market it as an export (Eigenberg et al., 1998). Because manure value is not recognized, it is often stored or applied in conditions which are not favorable.

To decrease environmental degradation and increase feed efficiency and nutrient recycling, USDA NRCS is cost sharing the installation of heavy use area protection (HUAP) and waste storage facilities (WSF) (USDA NRCS, 2015; USDA NRCS, 2012a). These structures are often roofed and provide a feeding and manure storage area for the winter and spring months when stored feeds are required and weather conditions can be unfavorable for animals and operators. Missouri Extension found that feeding large round bales without a ring feeder can result in losses between 12.3 and $43.0 \%$, while feeding within a ring in a confined area reduces loss to 4.9 to $5.4 \%$ in turn reducing need for import feed (Kallenbach, 2000).

A major concern with these structures is ensuring that once manure is captured, farms have adequate land area to apply it without causing an environmental concern (USDA NRCS, 2015; USDA NRCS, 2012a). Collected manure volume and manure nutrient concentrations must be estimated if a manure containment system is not present. Currently these are based on tabulated values (Purdue Research Foundation,2010; USDA NRCS, 2013) Animal manure $P$ concentrations are known to vary widely by species and production system, but there also is reason to suspect errors in the tabulated values (Rieck-Heinz et al, 1996). Dou et al. (2001) observed differences between book values and farm manure analysis for dairy cattle and swine. Other studies reported P concentration errors of between 20 and 40\% for dairy (Rieck-Heinz et 615 al., 1996; Lindley et al., 1983). Lindley et al. (1983) found that manure from animals fed diets that contained large amounts of P from feed stuffs such as barley and soybean meal, could vary from 50 to $100 \%$ from the tabulated value; only $\mathrm{K}_{2} \mathrm{O}$ had a direct correlation to feed intake. Deviations from published values and tested values appeared to be related to management, feed source, and manure handling (Lindsey et al., 1983). 


\section{Objective}

The primary objective of this study it to determine if NMB and manure book value are different in basic and complex operations utilizing HUAPs for winter feeding and manure storage to provide better $\mathrm{P}$ management recommendations.

\section{Materials and Methods}

All 12 operations used for categorization were used in either a NMB or manure book value comparison study. Since operators agreed to participate in the study, a WVU graduate student and summer intern visited the farm to take samples and complete a survey of management information to complete CNMPs as part of the previously mentioned cooperative agreement. This survey consisted of all information needed to develop a WV USDA NRCS approved CNMP.

When sampling was complete for a specific farm, decisions were made on its potential for further study. Farms were evaluated based on proximity to Morgantown, WV; record keeping; and willingness to provide personal farm details. Sampling of all operation followed the same methods because study determination was not made until after data collection was complete. Since undergraduate interns were used to collect most of the samples used in this research, standard procedures were developed for each sample type and included in the Appendices.

Soils were sampled at a depth of $4 \mathrm{~cm}$ for pasture and hay fields in a random zig-zag pattern, while crop fields were sampled at a depth of $15 \mathrm{~cm}$ in the same random zig-zag pattern. Sample area was dependent on management of the operation. Larger fields were divided only when the operator was willing to change management to match these divisions. A minimum of

64510 cores were taken per field to make composite and representative samples. Samples were sent to the West Virginia University Soil Test Lab for determination of Mehlich 1 extractable Mg, Ca, P, and K (Appendix F). Techniques followed recommended procedures published in Soil Science Society of America: Soil Testing and Plant Analysis (Westerman et al., 1990). Because samples were taken by WVU undergraduate interns, sampling protocols and directions were developed (Appendix F). Records were taken of sample number, sample area, fertilizer or manure applications, and the rate of any other nutrient applications. 
Manure samples were taken multiple times during the study to account for temporal changes in the effects of feed stuffs on manure P concentration. Each manure sample was taken as a composite sample of at least five subsamples. Subsamples were taken from different locations across the manure pile to accurately represent its nutrient concentrations. Subsamples were taken at least $45 \mathrm{~cm}$ from the surface of the pile. Subsamples were mixed in a clean container and sent to the WV Department of Agriculture for total manure nutrient analysis (Appendix G). Sampling techniques will follow “Manure Sampling and Analysis,” published by Rutgers Extension (Appendix G) (Rutgers Cooperative Research \& Extension, 2006).

Forage hay was sampled using Star Quality Samplers and grab samples were collected for silage and grain supplements. Samples were analyzed by Cumberland Valley Analytical Service (CVAS) using NIR and wet chemistry (Appendix H). Records were collected of bales produced, harvest number (first cut, second cut, etc.), and estimated bale weight. Techniques followed recommended procedure published in "Sampling Hay, Silage, and Total Mixed Rations for Analysis” (Appendix H) (Undersander et al., 2005). Dry hay samples were divided based on field and harvest number. At least 20 cores were taken to make the composite sample used by CVAS for analysis. Twenty cores or more will reduce error caused by potential variability within bales (Undersander et al., 2005). If a field produced more than 50 large round bales, it was divided into two samples of 25 bales each and an average analysis P value was used. Wrapped ensiled hay was sampled using the same method as dry hay. Corn silage was sampled using a grab composite method. Multiple grab samples were mixed to produce a representative sample. Number of subsamples were determined at the time of sampling. Techniques followed recommended procedures published in "Sampling Hay, Silage, and Total Mixed Rations for Analysis” (Undersander et al., 2005).

\section{Nutrient Mass Balance}

Five operations were selected from the categorization sample set used in Chapter 2 for a NMB assessment. Farms were selected based on proximity to Morgantown, WV and reliability of shared farm information. Sampling was conducted from May of 2015 through February 2017. Sampling consisted of quantitative analysis of soils, forages, and manure, and also qualitative analysis of farm management strategies and records.

Animal exports were determined from farm records. All farms sold calves at an average weight of $245 \mathrm{~kg}$ (550 lbs.). A linear equation was used to determine the amount of P within this 
weight animal based on a relationship developed by (Gibson et al., 2002) (Appendix H) for calves fed winter wheat.

Phosphorus concentrations in fertilizers, mineral supplements, and feeds were obtained from individual farm records. When a farm had records for multiple year's averages were used. Farms which imported manure applied it at a set rate and volume on a yearly basis. When applicable, exported hay was also determined using farm records. Removed P through hay was based on farm specific P composites from hay samples.

A net $\mathrm{P}$ balance was calculated by subtracting all exported $\mathrm{P}$ from all imported $\mathrm{P}$. Net $\mathrm{P}$ concentrations were then used to calculate land area use efficiency, as well as animal production efficiency (Cela et al., 2014). Land area efficiency was quantified on a kg manure P/spreadable hectare and animal efficiency on $\mathrm{kg} \mathrm{P} / \mathrm{kg}$ animal exported. These results were compared for individual operations, and as basic and complex operation categories. Efficiency of $\mathrm{P}$ recycling is a ratio of $\mathrm{P}$ and product, where a lower ration indicated a more efficient system. Phosphorous efficiency was then tested for statistical significance using ANOVA with PROC GLM (SAS v 9.4, SAS Institute, Cary, NC).

\section{Manure Book Values}

During the CNMP planning process, MMP used the AWMFH to calculate manure nutrient book values. This value was specific to each farm based on animal numbers, animal types, and storage type. A percent difference formula was calculated as, and compared using a single factor ANOVA.

$$
\frac{\text { Manure }_{\text {Analysis P }}-\text { Manure }_{\text {Book Value P }}}{\text { Manure }_{\text {Book Value P }}} * 100
$$

\section{Results}

\section{Nutrient Mass Balance}

Study farms ( $\mathrm{n}=5)$ (Table 3.1) (raw data table in Appendix I) were in two different geographical regions in the state, the Ohio River Valley $(n=4)$ and the Potomac Section $(n=1)$. Mean herd size was 29 with a range from 20 to 43. Mean production area was 29.3 ha with a range of 17.2 to 60.2 ha (Raw data in appendix D). Mean spreadable area was 14.9 ha with a range of 4.6 to 18.8. Production area was two times larger than spreadable area based on NRCS 
Manure Application Setbacks. Animal density had a mean value of 1.59 with a range from 1.17 to 2.82. Based on dry lot feeding, Farm 1, Farm 2, and Farm 3 were determined basic and Farm 4 and Farm 5 were determined complex.

All farms applied manure to forage hay land, as well as pasture land when needed. Farm 5 had the lowest amount of manure amended land because only 36\% of total farm area was in crop production. Farm 4 had the highest percent of manure amended area (88\%) due to a large hay meadow and poor soils in need of manure amendments to improve fertility. Farms 1, 2, and 4 imported commercial fertilizers to meet crop needs. Farm 5 imported animal manure. Farm 5 was located in the Potomac section of WV and imported poultry litter as a crop nutrient source. Farm 3 had enough manure nutrients to meet all cropping recommendations. All farms collected beef manure during indoor winter feeding, which was applied as a spring or fall fertilizer. Farms 1, 2, 3, and 4 made spring applications, and Farm 5 made fall applications.

The NMB calculations indicated that all farms had larger amounts of imported $\mathrm{P}$ than exported P. Net balances ranged from 75.2 to $943.1 \mathrm{~kg}$, with a mean value of $315 \mathrm{~kg}$ (Table 3.2) (Raw Data in Appendix K). Total import P ranged from 128.61 to $978.69 \mathrm{~kg}$ P with a mean value of 376.64. Total P exports ranged from 35.12 to $152.07 \mathrm{~kg} P$ with a mean value of 61.20. Basic operations ranged from 2.9 to $4.8 \mathrm{~kg} \mathrm{P}$ / spreadable hectares with a mean value of 3.7, while complex operations had a range from 11.3 to $54.9 \mathrm{~kg} \mathrm{P} /$ spreadable hectares with a mean value of 33.1. All operations had a mean value of $15.4 \mathrm{~kg}$ P/ spreadable hectares. Basic operations ranged from 0.015 to $0.022 \mathrm{~kg} \mathrm{P} / \mathrm{kg}$ animal produced with a mean value of 0.02 , while complex operations had a range from 0.062 to 0.151 with a mean value of $0.11 \mathrm{~kg} \mathrm{P} / \mathrm{kg}$ animal. The mean value for all operations was $0.055 \mathrm{~kg} \mathrm{P} / \mathrm{kg}$ animal produced.

Basic farms had a greater percentage of total imported $P$ from supplements and minerals than did complex operations. Complex farms had a higher percentage of their total coming from fertilizers and imported animal manures.

\section{Manure Book Value}

Participating operations $(\mathrm{n}=12)$ (Table 3.3) were in six counties and two geographical regions in West Virginia, the Ohio River Valley $(n=8)$ and the Potomac Section $(n=4)$. Three farms had multiple herds with separate feeding areas which resulted in 16 total manure samples. Farms were then categorized as basic and complex. Basic operations ( $n=4)$ and complex operations $(n=12)$ were fed in separate barns. Herd size ranged from 20 to 100 with a mean 
value of 42. Production area ranged from 17 to 104 ha with a mean value of 48, while spreadable area ranged from 10 to 41 ha with a mean value of 19 . Sixty-six percent of operations utilized dry-lot feeding.

The average book value for $\mathrm{P}$ in all manures $(\mathrm{n}=16)$ ranged from 0.66 to 0.99 with a mean value of $0.77 \mathrm{~kg} \mathrm{P} / \mathrm{Mt}$ (Table 3.3.). Basic manure $(\mathrm{n}=4) \mathrm{P}$ book value ranged from 0.73 to 0.77 with a mean value of $0.74 \mathrm{~kg} \mathrm{P} / \mathrm{Mt}$. Complex manure $(\mathrm{n}=12) \mathrm{P}$ book value ranged from 0.66 to 0.99 with a mean value of $0.78 \mathrm{~kg}$ P/ Mt. All manure had an analyzed P range from 1.06 to $4.28 \mathrm{~kg} \mathrm{P} / \mathrm{Mt}$ with a mean value of 1.72 . Basic manure had an analyzed P range from 1.11 to $1.33 \mathrm{~kg}$ P/ Mt with a mean value of 1.19. Complex manure had an analyzed P range from 1.06 to $4.28 \mathrm{~kg}$ P/ Mt with a mean value of 1.95. Mean analysis was compared to book value and was found to be significant with a p value less than 0.01 . All manure had a percent difference of $124 \%$. Basic manure had a mean difference of $61 \%$. Complex manure had a mean difference of $145 \%$.

All manure mean analysis differed from book values by $124 \%$, and was determined to be significantly different $(\mathrm{p}=<0.01)$. Basic manure book value and manure analysis $\mathrm{P}$ differed by $61 \%$, which was less than half of the difference percent of all farms. The mean book value was $0.78 \mathrm{~kg}$ P/ Mt, and the mean analysis value was $1.95 \mathrm{~kg} \mathrm{P} / \mathrm{Mt}$. Analysis of book value and analysis differed by $145 \%$ and was determined significant $(\mathrm{p}=<0.01)$.

\section{Discussion}

\section{Nutrient Mass Balance}

Phosphorus NMB can vary considerably across different farming operations. Basic farms had the lowest imported P/ kg animal exported (mean value of $0.02 \mathrm{~kg} \mathrm{P} / \mathrm{kg}$ animal). However, farms 1, 2, and 3 have the largest percentage from the whole for imported feed (mean $=75 \%$ ), while farms with dry lot feeding have a mean of $25 \%$ of imported P from feeds. This may be a consequence of open feeding. When the calves are not confined, they are in competition for grain with brood cows and other calves causing waste due to pushing and fighting. They are also being fed out in pasture which can increase the amount of waste. In confined settings calves are fed a more monitored diet which does not result in as much waste. Basic operations imported approximately $40 \%$ more grain than complex operations. A potential explanation for this is that complex operations use feeding bunks, which based on a study by Nebraska Extension, can 
reduce feeding waste by up to 40\%, (Musgrave et al., 2012). Farms did not feed on the ground, however more specific equipment like bunks and creep-feeders could still cause a reduction in loss.

Farm 4 imported hay from a neighboring farm without an offsetting manure removal. Imported hay accounted for $31.3 \mathrm{~kg} \mathrm{P}$ which was more than the farm export of calves (26.6 kg P) resulting in a net $\mathrm{P}$ balance of $102.0 \mathrm{~kg}$. Farm 2 also imported hay, but this was offset by its lack of grain imports and minimal mineral supplements. Farm 2 had the lowest net balance in the set because the management system was a foraged based with the smallest amount of imported P.

Farms 3 and 5, which utilized dry lot feeding, had higher $\mathrm{kg} \mathrm{P/} \mathrm{kg} \mathrm{animal} \mathrm{export} \mathrm{ratios.}$ Farm 3 showed a $0.06 \mathrm{~kg} \mathrm{P} / \mathrm{kg}$ animal and $11.3 \mathrm{~kg}$ P/ spreadable hectare, which is lower than the $0.15 \mathrm{~kg} \mathrm{P} / \mathrm{kg}$ animal produced and $54.9 \mathrm{~kg}$ P/ spreadable hectare calculated for Farm 5. The primary difference between these two farms is the importation of hay and the use of animal manure as a fertilizer. Farm 5 imported $978.69 \mathrm{~kg} P$ in animal manures as fertilizers, while exporting $\mathrm{P}$ at a rate of $35.1 \mathrm{~kg} \mathrm{P}$, which is below the mean. Farm 5 had the highest net $\mathrm{P}$ of $943.1 \mathrm{~kg}$, which was $198 \%$ greater than the mean value of $315.4 \mathrm{~kg}$ P. Offsetting P imports on Farm 4 was the exported P of 29.9 in hay, which allowed Farm 4 to be below the mean net P, even with dry-lot feeding.

Farms categorized as basic and complex were different in their efficiency and utilization of imported P. Basic operations had higher importation of grain due to non-confined feeding; however, they had a mean efficiency of $0.02 \mathrm{~kg}$ P/ kg animal produced. Complex operations had

795 better utilization of grains and supplements because of confined feeding, but had a higher mean efficiency of $0.11 \mathrm{~kg}$ P/ kg animal produced. Calculated P efficiency between basic and complex was statistically different ( $\mathrm{p}=<0.01$ ) which is consistent with using the presence of dry-lot feeding is a distinguishing management characteristic of forage based feeding operations in WV.

\section{Manure Book Values}

All operations had a mean difference of $124 \%$, while basic and complex categories had mean differences of $61 \%$ and $154 \%$ respectively. Statistical analysis proved that values for basic and complex operations were different $(\mathrm{p}=<0.01)$.

Complex farms had the largest difference and influenced the average difference in "All Operations” to be larger. This larger error is explained by complex operations having more intensive management and more imported $\mathrm{P}$ within the system. Complex operations use grain as 
a supplement to increase growth of calves during dry lot feeding, while basic operations do not. Grain feeding of livestock can increase manure P content due to higher pass through nutrients as a result of overfeeding. Grains and supplements have a higher $\mathrm{P}$ content than that of hay and forage. Animals on complex farms are fed a ration based on protein and not P intake. By

810 introducing feed management to these systems, manure P could be reduced by up to 35\% (Shraply et al., 2006).

Based on this research, manure book values and manure test values for $\mathrm{P}$ on WV cowcalf beef operations are not the same, and farms seeking new CNMPs in WV should be categorized as basic or complex to provide more accurate recommendations. Results indicate operations in WV which are considered basic and complex, should have an estimated manure value of $1.19 \mathrm{~kg} \mathrm{P} / \mathrm{Mt}$ and $1.95 \mathrm{~kg}$ P/ Mt, respectively, when developing a CNMP without analysis. 


\section{Literature Cited}

Cela, S., Ketterings, Q. M., Czymmek, K., Soberon, M., \& Rasmussen, C. (2014). Characterization of nitrogen, phosphorus, and potassium mass balances of dairy farms in New York State. Journal of dairy science, 97(12), 7614-7632. (Retrieved 4/4/2017).

Cornell University Cooperative Extension. (2014). Nutrient mass balance: fact sheet 25. Retrieved from http://nmsp.cals.cornell.edu/guidelines/factsheets.html. (Retrieved 4/4/2017).

Dou, Z., Galligan, D. T., Allshouse, R. D., Toth, J. D., Ramberg, C. F., \& Ferguson, J. D. (2001). Manure sampling for nutrient analysis. Journal of environmental quality, 30(4), 14321437. (Retrieved 4/4/2017).

Eigenberg, R. A., Korthals, R. L., Nienaber, J. A., \& Hahn, G. L. (1998). Implementation of a mass balance approach to predicting nutrient fate of manure from beef cattle feedlots. Applied Engineering in Agriculture, 14, 475-484. (Retrieved 4/4/2017).

Gibson, C. P., Horn, G. W., \& Krehbiel, C. R. (2002). Soil phosphorus removal by stocker cattle grazing winter wheat. Animal Science Research Report. Agricultural Experiment Station. Oklahoma State University. Retrieved from http://www.ansi.okstate.edu/research/reports/2002/. (Retrieved 4/4/2017).

Kallenbach, R. L. (2000). Reducing losses when feeding hay to beef cattle. Extension publications (MU). Retrieved from http://hdl.handle.net/10355/3531. (Retrieved 4/4/2017).

Lindley, J. A., Johnson, D. W., \& Clanton, C. J. (1988). Effects of handling and storage systems on manure value. Appl. Eng. Agric, 4(3), 246-252. (Retrieved 4/4/2017).

Purdue Research Foundation. (2010). Getting started with manure management planner. Retrieved from http://www.purdue.edu/agsoftware/mmp/MmpGuide.htm. (Retrieved 4/4/2017).

Rieck-Hinz, A. M., Miller, G. A., \& Schafer, J. W. (1996). Nutrient content of dairy manure from three handling systems. Journal of production agriculture, 9(1), 82-86. (Retrieved 4/4/2017).

Rutgers Cooperative Research \& Extension. (2006). Manure sampling and analysis. Retrieved from https://njaes.rutgers.edu/pubs/publication.asp?pid=E306. (Retrieved 4/4/2017).

Sharpley, A. N., Daniel, T., Gibson, G., Bundy, L., Cabrera, M., Sims, T., Stevens, R., Lemunyon, J., Kleinman, P., Parry, R. (2006). Best management practices to minimize agricultural phosphorus impacts on water quality. Retrieved from https://www.ars.usda.gov/research/publications/publication/?seqNo115=145857. (Retrieved 4/4/2017). 
855 Undersander, D., Shaver, R., Linn, J., Hoffman, P., \& Peterson, P. (2005). Sampling hay, silage, and total mixed rations for analysis. University of Wisconsin-Extension. Retrieved from https://www.rhizoterra.com/fileaccess/getfile/651.pdf. (Retrieved 4/4/2017).

USDA Natural Resources Conservation Service. (2012a). WV NRCS practice standard: waste storage facility. (Retrieved 4/4/2017).

USDA Natural Resources Conservation Service. (2013). WV NRCS practice standard: nutrient management. (Retrieved 4/4/2017).

USDA Natural Resources Conservation Service. (2015). WV NRCS practice standard: heavy use area protection. (Retrieved 4/4/2017).

Van Almelo, J., Ketterings, Q.M., and Cela, S. (2016). Integrating record keeping with whole farm futrient mass balance: a case study. Journal of Agricultural Science, 8(6):22. (Retrieved 4/4/2017).

Westerman, R.L., Baird, J. V., Christensen, N.W., Fixen, P.E., and Whitney, D.A. (1990). Soil testing and plant analysis. Madison, WI: Soil Science Society of America. (Retrieved 4/4/2017).

870 Wright, S., \& Mallia, C. (2008). The Dutch approach to the implementation of the nitrate directive: Explaining the inevitability of its failure. The Journal of Transdisciplinary Environmental Studies, 7(2), 1-16. (Retrieved 4/4/2017). 
Table 3.1. Farm characteristics used to calculate a nutrient mass balance for five West Virginia beef cattle farms.

\begin{tabular}{|c|c|c|c|c|c|c|}
\hline & \multicolumn{5}{|c|}{ Farms } & \multirow{3}{*}{ Mean } \\
\hline & \multicolumn{3}{|c|}{ Basic } & \multicolumn{2}{|c|}{ Complex } & \\
\hline & F1 & F2 & F3 & F4 & F5 & \\
\hline \multicolumn{7}{|l|}{ Farm Characteristics } \\
\hline Mature Cows & 43 & 30 & 20 & 20 & 30 & 29 \\
\hline Animal Units ${ }^{4}$ & 70.6 & 50.0 & 32.0 & 32.0 & 48.5 & 46.6 \\
\hline Production ha ${ }^{1}$ & 60.2 & 22.9 & 21.3 & 25.1 & 17.2 & 29.3 \\
\hline Spreadable ha ${ }^{2}$ & 12.7 & 13.1 & 18.8 & 14.4 & 4.6 & 14.5 \\
\hline \% Manure Amended & $21 \%$ & $57 \%$ & $88 \%$ & $75 \%$ & $27 \%$ & $40 \%$ \\
\hline Weight Sold (kg) ${ }^{3}$ & 9,730 & 4,990 & 4,536 & 4,536 & 6,237 & 6,006 \\
\hline \multicolumn{7}{|l|}{ Density } \\
\hline Animal Density (AU/ Production ha) & 1.17 & 2.18 & 1.50 & 1.27 & 2.82 & 1.59 \\
\hline Animal Exported (kg/ Production ha) & 162 & 218 & 213 & 181 & 363 & 205 \\
\hline \multicolumn{7}{|c|}{$\begin{array}{l}1=\text { Total area on which livestock can graze } \\
2=\text { Total area on which collected manure was applied } \\
3=\text { Total kg of live weight of animals sold from the farm } \\
4=\text { Animal Units reflects total AU (cows and calves) }\end{array}$} \\
\hline
\end{tabular}


Table 3.2. Calculated P imports and exported for five West Virginia beef cattle farms.

\begin{tabular}{|c|c|c|c|c|c|c|}
\hline & \multicolumn{5}{|c|}{ Farms } & \multirow{3}{*}{ Mean } \\
\hline & \multicolumn{3}{|c|}{ Basic } & \multicolumn{2}{|c|}{ Complex } & \\
\hline & F1 & $\mathrm{F} 2$ & F3 & $\mathrm{F} 4$ & F5 & \\
\hline & \multicolumn{6}{|c|}{ Imports } \\
\hline & \multicolumn{6}{|c|}{---------------------------------------kg----------------------------------- } \\
\hline Hay P & 0.00 & 66.30 & 31.30 & 0.00 & 0.00 & 19.52 \\
\hline Total Supplement P & 90.81 & 0.00 & 56.25 & 56.25 & 129.92 & 66.64 \\
\hline Total Mineral P & 130.28 & 9.40 & 41.06 & 30.71 & 115.58 & 65.41 \\
\hline Fertilizer P & 104.97 & 34.60 & 0.00 & 252.61 & 0.00 & 78.44 \\
\hline Total Imported Manure P & 0.00 & 0.00 & 0.00 & 0.00 & 733.20 & 146.64 \\
\hline \multirow[t]{3}{*}{ Total Imported P } & 326.06 & 110.29 & 128.61 & 339.57 & 978.69 & 376.64 \\
\hline & \multicolumn{6}{|c|}{ Exports } \\
\hline & \multicolumn{6}{|c|}{ |---------------------------------------|kg------------------------------------- } \\
\hline Hay P & 96.52 & 6.63 & 0.00 & 29.94 & 0.00 & 26.62 \\
\hline Total Livestock P & 55.55 & 28.49 & 26.64 & 26.64 & 35.61 & 34.59 \\
\hline Total Exported P & 152.07 & 35.12 & 26.64 & 56.58 & 35.61 & 61.20 \\
\hline Net Phosphorus & 174.0 & 75.2 & 102.0 & 283.0 & 943.1 & 315.4 \\
\hline kg P/ Spreadable ha & 2.9 & 3.3 & 4.8 & 11.3 & 54.9 & 15.4 \\
\hline kg P/ kg Produced & $0.018^{\mathrm{a}}$ & $0.015^{\mathrm{a}}$ & $0.022^{\mathrm{a}}$ & $0.062^{\mathrm{b}}$ & $0.151^{\mathrm{b}}$ & 0.055 \\
\hline
\end{tabular}


Table 3.3. Descriptive statistics for farm characteristics of twelve beef cattle four basic operations, and eight complex

\begin{tabular}{|c|c|c|c|c|c|c|c|c|c|c|c|c|}
\hline \multirow[b]{2}{*}{ Characteristics } & \multicolumn{4}{|c|}{ All Farms $(n=12)$} & \multicolumn{4}{|c|}{ Basic Farms $(n=4)$} & \multicolumn{4}{|c|}{ Complex $(\mathrm{n}=8)$} \\
\hline & Mean & $\mathrm{SD}$ & Min & Max & Mean & $\mathrm{SD}$ & Min & Max & Mean & SD & Min & $\operatorname{Max}$ \\
\hline \multicolumn{13}{|l|}{ Farm Size } \\
\hline Herd Size & 42 & 23 & 20 & 100 & 29 & 9 & 20 & 43 & 51 & 27 & 20 & 100 \\
\hline Animal Units & 50 & 8 & 24 & 120 & 48 & 14 & 32 & 71 & 85 & 46 & 32 & 168 \\
\hline Production ha & 48 & 30 & 17 & 104 & 34 & 18 & 20 & 60 & 59 & 34 & 17 & 104 \\
\hline Spreadable ha & 19 & 9 & 10 & 41 & 17 & 8 & 10 & 30 & 21 & 9 & 13 & 41 \\
\hline \multicolumn{13}{|l|}{ Herd Management } \\
\hline Dry-lot Feeding* & $66 \%$ & & & & $0 \%$ & & & & $100 \%$ & & & \\
\hline Animals Sold & 38 & 23 & 16 & 95 & 25 & 8 & 16 & 38 & 47 & 27 & 16 & 95 \\
\hline \multicolumn{13}{|l|}{ Density } \\
\hline AU/ production ha & 1.6 & 0.6 & 0.7 & 2.8 & 1.6 & 0.5 & 1 & 2.2 & 1.6 & 0.7 & 0.7 & 2.8 \\
\hline AU/ spreadable ha & 3.7 & 1.3 & 1.5 & 5.6 & 3.3 & 1.7 & 1.5 & 5.6 & 3.9 & 1.0 & 2.1 & 5.2 \\
\hline
\end{tabular}

* Signifies an average of farms participating in the specific management.

Yes to the question $=1$ and $\mathrm{No}=0$ 
Table 3.4. Manure phosphorus book value and analysis comparison for sixteen samples from four basic operations and twelve complex operations.

\begin{tabular}{|c|c|c|c|c|c|c|c|c|c|c|c|c|}
\hline \multirow[b]{2}{*}{ Characteristics } & \multicolumn{4}{|c|}{ All Samples $(\mathrm{n}=16)$} & \multicolumn{4}{|c|}{ Basic Samples $(n=4)$} & \multicolumn{4}{|c|}{ Complex Samples $(\mathrm{n}=12)$} \\
\hline & Mean & $\mathrm{SD}$ & Min & Max & Mean & SD & Min & Max & Mean & SD & Min & Max \\
\hline \multicolumn{13}{|l|}{ Manure } \\
\hline Book Value & 0.77 & 0.09 & 0.66 & 0.99 & 0.74 & 0.02 & 0.73 & 0.77 & 0.78 & 0.10 & 0.66 & 0.99 \\
\hline Percent Difference & $124 \%$ & & & & $61 \%$ & & & & $145 \%$ & & & \\
\hline
\end{tabular}

\footnotetext{
${ }^{a}=p$ value is $<0.01$

$\mathrm{b}=\mathrm{p}$ value is $<0.01$
}

$\mathrm{c}=\mathrm{p}$ value is $<0.01$ 


\section{Chapter 4: Discussion and Recommendations}

As the interest in HUAPs and WSFs by beef cattle farmers in WV increases, so does the need for accurate conservation planning and $\mathrm{P}$ management. A major step in this process is using a categorization system based on management strategies rather than herd size and gross profit.

885 Now that there is a basis for a preliminary categorization based on dry-lot feeding, future research can be directed to improve recommendations for P management.

\section{Nutrient Mass Balance}

Nutrient mass balance was an effective way to determine if operations are recycling nutrients efficiently, as well as assessing operational differences. A major difference found in this study was the P imports for basic and complex operations. Basic operations imported the majority of their P from feeds and minerals, while complex operations imported their P from fertilizers and animal manures. This difference was evident in differences in actual and theoretical P (Appendix N). A possible reason for this difference is that basic operations want more direct growth from animals, while complex operations are focused more on crop production.

Based on net $\mathrm{P}$ and the collected manure estimates, $\mathrm{P}$ balances were positive in basic systems and negative in complex systems. Because of higher amounts of imported manure and fertilizer, the soil P on complex operations values averaged at $445.9 \mathrm{~kg}$ P/ha, which was much

900 higher than necessary to be productive. At this soil P level, plants cannot use all that is applied and soil loading has occurred. Since the excess $\mathrm{P}$ is in the soils, it does not appear in a NMB because it is not recycled. In basic operations, manure analysis was higher than theoretical net $\mathrm{P}$ supporting the idea that they had higher percentages of imported $\mathrm{P}$ in feeds. Currently it shows in a NMB, but over time if soils become loaded recycling efficiency will decrease. Other causes of this difference are unaccounted bedding $\mathrm{P}$ content, losses of manure during periods of outdoor feeding, and inaccuracies of farm records. Nutrient mass balance should be studied in the future for this sample to determine if predictions of P management, in regards to cropping needs and soil $\mathrm{P}$ accumulations, are accurate.

Soil P accumulations on a spreadable area basis were calculated form manure analysis and net P from NMB (Appendix N). Farm specific hay P removal was used to compare 
applications and removals to determine a yearly P balance. All operations are projected to increase soil P annually. These predictions assume that applications will follow the newly implemented CNMP and manure will only be applied to the spreadable area. One explanation for all farms increasing field balance is the reduction of their individual spreadable area. Another

915 explanation is that farms are simply importing more $\mathrm{P}$ than can be recycled on a yearly basis.

Future sampling and NMB evaluation on these operations will improve predictions. Multiple years and a larger sample of NMB will provide a better benchmark for comparison. If soils in spreadable areas reach projected levels, then $\mathrm{P}$ imports should be reduced or considerations for exporting manure should be incorporated into the CNMP.

Soils that exceed projected levels could be explained by an increased P import to either soils as fertilizer and manure or indirectly through feeds. They could also be explained by weather variability. Depending on weather conditions, collected manure volumes may be smaller if more outdoor feeding is possible. If over time soils do not show the increase projected, a possible explanation is that manure was applied in areas that were determined non-spreadable. Pre-plan applications were made on a larger portion of all operations and it is believed that without enforcement of these regulations, no change in application area will be made by operators. Another cause of soil levels not reaching projected levels could be inaccuracy in operator records. Since the study was voluntary there was no way to verify if records and data provided were accurate. If records are inaccurate, manure volume may be too high, reducing the available P for application.

\section{Manure Book Values}

The book value errors from this research were larger than those previously reported. One explanation may be that the AWMFH book values are a national average and that local and regional beef production systems deviate from national practices. This would indicate a need for more localized estimates. Future research should be directed at determining why the error for complex operations is so large. There are likely opportunities to divide the complex categories into sub-categories. 


\section{Future Research}

During discussion of both NMB and manure book value, areas of future research were outlined. The first area of future research is bedding. Bedding is used to make animals more comfortable and as an absorbent of effluent from running out of the HUAPs and WSFs. Eigenberg et al. (1998) found that up to $20 \%$ of collected phosphorus can be in a liquid state during the winter and spring, which can be lost as runoff or through transport of manure. Conversely, research from Sweeten and Wolfe (1994) and Eghball and Power (1994) suggested that WSFs which are sized and managed properly, lose less than $2 \%$ of $\mathrm{P}$ during storage and composting. Another benefit of having a standard suggested method of bedding is that manure P content can be analyzed and interpreted to reflect the P content from bedding (Eigenberg et al., 1998). Currently WV does to have a standard bedding recommendation and if bedding was further researched manure P could be analyzed to reflect for residual P in bedding. If bedding is imported, it could also be a key component to NMB that would reduce error in manure and net P.

Another area of potential research is lengths of outdoor feeding period and the presence of nutrient hot spots. Conditions for HUAPs to be completely successful are very narrow and do not often occur, because HUAPs are usually not designed for total confined of brood cattle, they are free to coma and go as they choose. In less than ideal situations issues of animal health and difficulties in feeding animals can present major problems. In periods of extreme wetness, alley ways and surrounding loafing areas can become saturated and turn into a deep mixture of mud, feces, and urine. These areas not only become nutrient hot spots, but are a hazard for cows and

960 calves. To reduce hot spots adjacent to HUAPs, cattle should be dispersed onto suitable grassland to rest and ruminate. Adding heavy use area laneways from these loafing area to the HUAPs would improve nutrient cycling on farms. Both scenarios present challenges for evaluating nutrient recycling. When access is limited animals are either fed outside of the HUAP where manure cannot be collected or fed inside the barn in a total confinement scenario When fed in fields, nutrients are deposited in areas where it is not accounted for. These areas often lose vegetative cover and when lacking cover, $\mathrm{P}$ within these areas cannot be harvested by either livestock or equipment as forage. Without forage removed $\mathrm{P}$, it cannot be placed elsewhere on the farm as part of recycling. If soils were sampled in these areas a more complete view of nutrient location and recycling could be obtained. Future research could also be conducted on the movement of $\mathrm{P}$ when animals are encouraged to move to other areas of the operation, rather than 
just adjacent loafing areas. By encouraging animals with water, minerals, or other feed to move to pastures or hay fields elsewhere on the operation, nutrients consumed by the cows in HUAPs could be relocated without the use of equipment. Another area where hot spots can occur is when manure volume is larger than the WSF can contain and manure must be stored uncovered.

975 Eghball and Power (1994) concluded that all P lost during manure stacking was due to runoff. Reducing manure volume isn’t always a concern, but in this study Farm 3 was forced into outdoor storage because the WSF was designed for 30-day storage. Excess volume leads to winter manure applications. The manure storage site should be sampled after manure is removed as part of continued research for manure hotspots around HUAPs.

Another area of future research is feed management. Sharpley et al. (2006) found that by reducing animal $\mathrm{P}$ intake, the area to recycle manure will decrease. Not only does this reduce environmental concern and make operation P use efficiency higher, but it saves money by reducing the need to import feeds. As animal intake is reduced, manure volume is reduced, along with a reduced nutrient content in the manure. Forage samples could be used to develop feed management plans specific to operations and animal needs. A revised standard for feed management would encourage more farmers to increase consideration of their feeding practices.

\section{Improved Recommendations for Future CNMPs}

Based on the data collected, categorizing farms based on dry-lot feeding as basic or 990 complex can increase the accuracy at which CNMPs can be written. Future recommendations should start with the more specific manure P contents of $1.19 \mathrm{~kg}$ P/MT for basic and $1.95 \mathrm{~kg}$ P/MT for complex operations. The next recommendation for CNMPs is to explore options of livestock loafing in multiple areas to encourage nutrient movement and recycling. Not only will this increase P utilization efficiency, but will reduce land degradation during the winter months. The last suggestion is to rewrite the standard for animal feed management and make it an associated practice. Being more precise and limiting pass through nutrients will reduce manure $\mathrm{P}$ and manure volume. 


\section{Literature Cited:}

Dou, Z., Galligan, D. T., Allshouse, R. D., Toth, J. D., Ramberg, C. F., \& Ferguson, J. D. (2001). Manure sampling for nutrient analysis. Journal of environmental quality, 30(4), 14321437. (Retrieved 4/4/2017).

Dou, Z., Galligan, D. T., Allshouse, R. D., Toth, J. D., Ramberg, C. F., \& Ferguson, J. D. (2001). Manure sampling for nutrient analysis. Journal of environmental quality, 30(4), 14321437. (Retrieved 4/4/2017).

Eghball, B., \& Power, J. F. (1994). Beef cattle feedlot manure management. Journal of Soil and Water Conservation, 49(2), 113-122. (Retrieved 4/4/2017).

Eigenberg, R. A., Korthals, R. L., Nienaber, J. A., \& Hahn, G. L. (1998). Implementation of a mass balance approach to predicting nutrient fate of manure from beef cattle feedlots. Applied Engineering in Agriculture, 14, 475-484. (Retrieved 4/4/2017).

Lindley, J. A., Johnson, D. W., \& Clanton, C. J. (1988). Effects of handling and storage systems on manure value. Appl. Eng. Agric, 4(3), 246-252. (Retrieved 4/4/2017).

Sharpley, A. N., Daniel, T., Gibson, G., Bundy, L., Cabrera, M., Sims, T., Stevens, R., Lemunyon, J., Kleinman, P., Parry, R. (2006). Best management practices to minimize agricultural phosphorus impacts on water quality. Retrieved from https://www.ars.usda.gov/research/publications/publication/?seqNo115=145857. (Retrieved 4/4/2017).

Sweeten, J. M., \& Wolfe, M. L. (1994). Manure and wastewater management systems for open lot dairy operations. Transactions-American Society of Agricultural Engineers, 37, 11451145. (Retrieved 4/4/2017). 
Appendix A: General Requirements for Study Participation 


\section{Farm Precipitation Requirements}

If the farm meets the following criteria, please contact the landowner/ operator and explain the project. If he or she expresses interest, an appointment will be scheduled between the landowner/ operator, NRCS representatives, and WVU graduate student and intern. This will be a brief meeting to further examine eligibility.

\section{Requirements for participation:}

USDA-NRCS cooperating farmer

Operating a HUAP and WSF to confine and/or winter feed

Using an existing CNMP or will use newly developed plan

Between 15 and 100 brood cows

Predominantly feeding mixed grass hay as winter forage

Pasture during growing season

Agreeable to sampling and record keeping as participation in study

Records are kept of any imported manure, fertilizer, and feeds. 
Appendix B: Initial Farm Categorization Questionnaire 


\begin{tabular}{|c|l|}
\hline \multicolumn{2}{|l|}{ Location: } \\
\hline \multicolumn{2}{|c|}{ Age of Building/ Contract: } \\
\hline Number of Head & \\
\hline Number of Acres & Hay: \\
\hline Grazing Management (Rotational, \\
Continuous) & Crop (Rotation): \\
\hline Calving Strategy & \\
\hline (Sell and Replacement) & \\
\hline Feeding Strategy (Hay, Pasture, Grain, etc.) & \\
\hline Exports (Manure, Hay, Grain, etc.) & \\
\hline
\end{tabular}


Appendix C: Questionnaire for developing CNMP through MMP 


\section{Manure Management Planner Check List:}

Pre-Farmer Activities: This document is designed to help you be prepared for a visit with an NRCS cooperator. This provides an accurate way to ensure that you have all data and questions answered quickly and accurately. Examples of the data and information you will needed are provided in this document in EXAMPLE tables. These tables will allow you to collect and organize your data in a way that will make CNMP development through MMP more efficient. Unfilled versions of these tables are provided to you.

\section{Read all sections before the farm visit and before marking on maps and filling in tables}

\section{Printed maps of the farm (Either from ToolKit or from a different mapping system)}

- It may be beneficial to have a few different color pens, markers, or highlighters for drawing features on the maps

- Get maps from NRCS for the property. These maps should show the field and tract boundaries, as well as a topo map so that you can see the slope of the land.

o You may want to have multiple pages with larger scales, rather than a single page and a small scale.

\section{Printed all tables}

- Do you have rotation builder tables? (Make sure you have extras in case of mistakes)

- Do you have printed RUSLE2 builder tables? (Make sure you have extras in case of mistakes)

\section{Information gathered from previous CNMPs or field office cooperator contracts?}

- Length of the plan?

o This information is key for knowing the duration you need for the rotation builder and the RUSLE2 builder

- Do you have current soil test and manure analysis results? (This includes imported manure)

o Ask the operator when samples were taken. Duplicates can often be obtained from testing labs.

o If they do not know, make plans with the cooperator for you to come back and sample 


\section{Farm Visit Activities:}

- Water: This is when different color inks are necessary.

o Creeks (perennial and intermittent) shown in correct location on the maps?

o Ponds shown in correct locations

o Lakes and/or reservoirs shown in the correct locations

o Wells on the property

- You must distinguish between agriculture wells and residential wells

- Greater than 30\% slope

o If so, outline them on the map to be excluded from spreadable area

- Artificial drainage

o Tiled or surface drains

o Grassed waterways (If the waterways are part of a NRCS contract, they may already be shown on the map)

- Mark all occupied dwellings on and adjacent to the property

\section{Filling out the rotation builder tables:}

- The rotation builder is a table designed for the rotation of the fields within a specific cropping cycle. This builder can be used multiple fields. With fields using the same rotation, complete the "Rotation Year" table

- A rotation builder must be completed for every cropping cycle.

- Even if permanent pasture, make a rotation builder with the fields it applies to. This will reduce mistakes and lack of data when trying to enter it into MMP.

\section{Storage:}

- If a block is shaded, you will not need to collect data for that dimension for that storage type.

- Manure on hand is used to start the planning process. It needs to be as close as possible, but can be an estimate.

- Is manure imported to the farm?

o If so, ID the storage "Imported Manure" and collect the same data 


\section{Animals:}

- Establish animal ID groups?

o These are the groups that are fed and managed in the same way

- Establish type and phase of the animals

o Age of the animal is important to determining the phase

o This will be the mainly described by the end use of the animal, milk, eggs, beef, etc.

- Present from and through is used for indicating if animals are only present for a specific period.

- Manure collection \% is an estimate based on the dry lot feeding time and storage type

- Extra water or bedding

o If so, indicate in the table.

o For bedding, it may be in tons/production period. Calculations will have to be made when you return to the office

- Associate each animal ID with a storage ID

Equipment

- Establish an ID for each piece of equipment used to apply manure and the type of manure it is used with

o Use a name provided by cooperator calls it so he/she can understand their CNMP

- Capacity of the equipment

o Establish units with the cooperator depending on the type of manure it spreads

- Minimum application rate of the equipment

o The cooperator may not know this information, but with the name of the spreader it can be determined online

- Application width or area

o This is the distance that is covered by the spreader on a single pass

- If the cooperator fertilizes through irrigation, collect this data here

Nutrient Management

- Fertilizer as a row starter

o If so, what is the composition and rate

- Commercial fertilizer 
o If so, record composition and rate

- Fields that receive manure

o This could be very different depending on the time of year and the crop

o If application is dependent on rotation, note that in the "Nutrient Management" table

o Record the month of application, rate, type of manure, and the equipment used to apply it

o If it is a smaller farm, applications may be easier to record using tract and field numbers rather than rotation 
RUSLE2 Builder for Tract and Field \# _ EXAMPLE

\begin{tabular}{|c|c|c|c|}
\hline Date & Operation & Vegetation & $\begin{array}{c}\text { Target } \\
\text { Yield } \\
\text { (Units) }\end{array}$ \\
\hline $4 / 15 / 0$ & Moldbord plow & & \\
\hline $4 / 25 / 0$ & Roller Harrow & & \\
\hline $5 / 15 / 0$ & Double disk opnr w/fluted coulter planter & Corn, Grain & $150 \mathrm{Bu}$ \\
\hline $10 / 26 / 0$ & Harvest grain and leaving 14” stubble & & \\
\hline $10 / 26 / 0$ & Shredded with rotary mower & & \\
\hline 11/1/0 & Double disk drill & Rye as winter cover & \\
\hline $4 / 15 / 1$ & Moldbord plow & & \\
\hline $4 / 22 / 1$ & Disk, tandem light finish & & \\
\hline $4 / 30 / 1$ & Drill double disk, with fluted coulters & Alfalfa/oat nurse crop & $60 \mathrm{Bu}$ \\
\hline $7 / 31 / 1$ & Harvest legume hay & Alfalfa, spring regrowth & 2 tons \\
\hline $6 / 15 / 2$ & Harvest legume hay & Alfalfa spring regrowth & 4 tons \\
\hline $8 / 21 / 2$ & Harvest legume hay & Alfalfa year 2 regrowth & 4 tons \\
\hline $6 / 15 / 3$ & Harvest legume hay & Alfalfa spring regrowth & 4 tons \\
\hline $8 / 21 / 3$ & Harvest legume hay & Alfalfa year 2 regrowth & 4 tons \\
\hline $4 / 15 / 4$ & Moldbord plow & & \\
\hline $4 / 25 / 4$ & Roller Harrow & & \\
\hline $5 / 15 / 4$ & Double disk opener w/fluted coulter planter & Corn, Grain & $150 \mathrm{Bu}$ \\
\hline $10 / 26 / 4$ & Harvest grain and leaving 14” stubble & & \\
\hline $10 / 26 / 4$ & Shredded with rotary mower & & \\
\hline $11 / 1 / 4$ & Double disk drill & Rye as winter cover & \\
\hline
\end{tabular}


Rotation Builder EXAMPLE

\begin{tabular}{|c|c|c|}
\hline Year & Vegetation & Yield Goal (Unit) \\
\hline 1 & Corn Grain & $150 \mathrm{Bu}$ \\
\hline 2 & Corn Grain & $150 \mathrm{Bu}$ \\
\hline 3 & Alfalfa (New) & 1 ton \\
\hline 4 & Alfalfa (Maintenance) & 4 tons \\
\hline 5 & Alfalfa (Maintenance) & 4 tons \\
\hline 6 & ------------------------ & ------------------------ \\
\hline 7 & ------------------------- & ------------------------ \\
\hline 8 & ------------------------ & -----------------------. \\
\hline
\end{tabular}

Year of Tract and Field within the Rotation EXAMPLE

\begin{tabular}{|c|c|l|c|l|c|}
\hline Tract and Field \# & $\begin{array}{c}\text { Year of } \\
\text { Rotation }\end{array}$ & Tract and Field \# & $\begin{array}{c}\text { Year of } \\
\text { Rotation }\end{array}$ & Tract and Field \# & $\begin{array}{c}\text { Year of } \\
\text { Rotation }\end{array}$ \\
\hline $798-1$ & 1 & & & & \\
\hline $798-8$ & 1 & & & & \\
\hline $798-30$ & 1 & & & & \\
\hline $798-3$ & 2 & & & & \\
\hline $1476-2$ & 2 & & & & \\
\hline $2309-4$ & 2 & & & & \\
\hline & & & & & \\
\hline & & & & & \\
\hline & & & & & \\
\hline & & & & & \\
\hline
\end{tabular}


Storage Type and Capacity EXAMPLE

\begin{tabular}{|c|c|c|c|c|c|c|c|c|}
\hline \multirow[b]{2}{*}{ Storage ID } & \multirow[b]{2}{*}{ Storage Type } & \multirow[b]{2}{*}{ Shape } & \multicolumn{6}{|c|}{ Dimensions (Feet) } \\
\hline & & & Diameter & Depth & Freeboard & Width & Length & $\begin{array}{c}\text { Slope } \\
\text { (horiz. to } 1 \\
\text { ft. vert) }\end{array}$ \\
\hline Slurrystore & Outside tank- Liquid & Circular & 55 & 30 & 3 & & & \\
\hline & & Circular & & & & & & \\
\hline & & Circular & & & & & & \\
\hline Red Barn & Manure Pack & Rectangle & & 7 & 1 & 40 & 32 & \\
\hline & & Rectangle & & & & & & \\
\hline & & Rectangle & & & & & & \\
\hline & & Rectangle w/ Sloping sides & & & & & & \\
\hline & & Rectangle w/ Sloping sides & & & & & & \\
\hline & & Rectangle w/ Sloping sides & & & & & & \\
\hline
\end{tabular}

\section{Manure on hand EXAMPLE}

\begin{tabular}{|c|c|}
\hline Storage ID & Manure on hand (Include units) \\
\hline Slurrystore & 500,000 gal \\
\hline Red Bard & 200 tons \\
\hline & \\
\hline & \\
\hline & \\
\hline & \\
\hline & \\
\hline & \\
\hline & \\
\hline
\end{tabular}


Animal ID and Info EXAMPLE

\begin{tabular}{|c|c|c|c|c|c|c|c|c|}
\hline Animal ID Group & $\begin{array}{l}\text { Animal type and } \\
\text { production phase }\end{array}$ & $\begin{array}{c}\text { Avg } \\
\text { Weight } \\
\text { (lbs) } \\
\end{array}$ & $\begin{array}{l}\text { \# of } \\
\text { Head }\end{array}$ & $\begin{array}{l}\text { Present on } \\
\text { farm? }\end{array}$ & $\begin{array}{c}\text { Manure } \\
\text { Stored } \\
(\%) \\
\end{array}$ & $\begin{array}{c}\text { Extra Water } \\
\text { (gal/day/head) }\end{array}$ & Bedding & $\begin{array}{l}\text { Associated } \\
\text { Storage }\end{array}$ \\
\hline Mature Cows & Milk Cows & 1,200 & 80 & Year round & 90 & 2.5 & & Slurrystore \\
\hline Calves & $\begin{array}{c}\text { Growing } \\
\text { steer/heifer }\end{array}$ & 900 & 15 & Year round & & & & Red Barn \\
\hline & & & & & & & & \\
\hline & & & & & & & & \\
\hline & & & & & & & & \\
\hline & & & & & & & & \\
\hline & & & & & & & & \\
\hline & & & & & & & & \\
\hline & & & & & & & & \\
\hline & & & & & & & & \\
\hline
\end{tabular}

\section{Equipment Specifications EXAMPLE}

\begin{tabular}{|c|c|c|c|c|}
\hline Equipment ID & Application Type & Capacity (Units) & Minimum Rate (Units) & $\begin{array}{c}\text { Application } \\
\text { Width (Units) }\end{array}$ \\
\hline Box Spreader & Solid Manure & 7 tons & 20 ton/acre & 14 feet \\
\hline Honey Wagon & Surface applied Liquid & 27,000 gal & 3,000 gal/acre & 25 feet \\
\hline & & & & \\
\hline & & & & \\
\hline
\end{tabular}


Nutrient Management EXAMPLE

\begin{tabular}{|c|c|c|c|c|}
\hline $\begin{array}{l}\text { Fertilizer } \\
\text { Type }\end{array}$ & $\begin{array}{l}\text { Composition } \\
\text { (If commercial) }\end{array}$ & $\begin{array}{c}\text { Application } \\
\text { Rate }\end{array}$ & Application Date & Notes \\
\hline Row Starter & 19-19-19 & 100 lbs/acre & May (Corn Planting) & \\
\hline Slurrystore & & $\begin{array}{l}5,000 \\
\text { gal/acre }\end{array}$ & $\begin{array}{c}\text { May (Newly planted } \\
\text { corn and Alfalfa) }\end{array}$ & \\
\hline Slurrystore & & $\begin{array}{l}\text { 3,000 } \\
\text { gal/acre }\end{array}$ & $\begin{array}{c}\text { October (On } \\
\text { maintenance alfalfa) }\end{array}$ & $\begin{array}{l}\text { Mainly alfalfa, but will } \\
\text { be applied to the poorest } \\
\text { looking of the forage } \\
\text { fields }\end{array}$ \\
\hline Red Barn & & $\begin{array}{l}1 \text { year } P \\
\text { needs }\end{array}$ & October & $\begin{array}{l}\text { Apply this to the fields } \\
\text { closest to the barn that } \\
\text { are in maintenance }\end{array}$ \\
\hline & & & & \\
\hline & & & & \\
\hline & & & & \\
\hline & & & & \\
\hline & & & & \\
\hline & & & & \\
\hline & & & & \\
\hline & & & & \\
\hline & & & & \\
\hline & & & & \\
\hline & & & & \\
\hline & & & & \\
\hline & & & & \\
\hline
\end{tabular}


Appendix D: Raw Farm Categorization Data 


\begin{tabular}{|c|c|c|c|c|c|c|c|c|c|c|c|c|}
\hline \multicolumn{13}{|c|}{ Farm Characterization Raw Data } \\
\hline & F1 & F2 & F3 & F4 & F5 & F6 & F7 & F8 & F9 & F10 & F11 & F12 \\
\hline \multicolumn{13}{|l|}{ Farm Size } \\
\hline Cow Herd Size (n) & 43 & 26 & 20 & 20 & 30 & 28 & 30 & 42 & 70 & 100 & 40 & 55 \\
\hline Animal Units (AU) & 51.6 & 31.2 & 24.0 & 24.0 & 36.0 & 33.6 & 36.0 & 50.4 & 84.0 & 120.0 & 48.0 & 66.0 \\
\hline Calf Herd Size (n) & 38 & 22 & 16 & 16 & 28 & 22 & 25 & 39 & 68 & 95 & 37 & 52 \\
\hline Animal Units (AU) & 19 & 11 & 8 & 8 & 14 & 11 & 12.5 & 19.5 & 34 & 47.5 & 18.5 & 26 \\
\hline Total (AU) & 70.6 & 42.2 & 32.0 & 32.0 & 50.0 & 44.6 & 48.5 & 69.9 & 118.0 & 167.5 & 66.5 & 92.0 \\
\hline Production Area (ha) & 60.2 & 20.0 & 25.1 & 21.3 & 22.9 & 44.3 & 17.2 & 104.0 & 68.4 & 92.7 & 36.0 & 68.0 \\
\hline Spreadable Area (ha) & 12.7 & 10.2 & 14.9 & 3.8 & 13.1 & 29.5 & 4.6 & 20.2 & 22.7 & 40.9 & 17.2 & 20.2 \\
\hline Dry Lot Feeding & $\mathrm{N}$ & $\mathrm{N}$ & $\mathrm{Y}$ & $\mathrm{N}$ & $\mathrm{N}$ & $\mathrm{N}$ & $\mathrm{Y}$ & $\mathrm{Y}$ & $\mathrm{Y}$ & $\mathrm{Y}$ & $\mathrm{Y}$ & $\mathrm{Y}$ \\
\hline Imported Manure & $\mathrm{N}$ & $\mathrm{N}$ & $\mathrm{N}$ & $\mathrm{N}$ & $\mathrm{N}$ & $\mathrm{Y}$ & $\mathrm{Y}$ & $\mathrm{N}$ & $\mathrm{N}$ & $\mathrm{N}$ & $\mathrm{N}$ & $\mathrm{N}$ \\
\hline Imported Fertilizer & $\mathrm{Y}$ & $\mathrm{Y}$ & $\mathrm{Y}$ & $\mathrm{Y}$ & $\mathrm{Y}$ & $\mathrm{N}$ & $\mathrm{N}$ & $\mathrm{Y}$ & $\mathrm{N}$ & $\mathrm{Y}$ & $\mathrm{Y}$ & $\mathrm{Y}$ \\
\hline \multicolumn{13}{|l|}{ Feeding } \\
\hline Grown Forage & $\mathrm{Y}$ & $\mathrm{Y}$ & $\mathrm{Y}$ & $\mathrm{Y}$ & $\mathrm{Y}$ & $\mathrm{Y}$ & $\mathrm{Y}$ & $\mathrm{Y}$ & $\mathrm{Y}$ & $\mathrm{Y}$ & $\mathrm{Y}$ & $\mathrm{Y}$ \\
\hline Imported Forage & $\mathrm{N}$ & $\mathrm{N}$ & $\mathrm{N}$ & $\mathrm{N}$ & $\mathrm{Y}$ & $\mathrm{N}$ & $\mathrm{N}$ & $\mathrm{N}$ & $\mathrm{N}$ & $\mathrm{N}$ & $\mathrm{N}$ & $\mathrm{N}$ \\
\hline Grown Grain & $\mathrm{N}$ & $\mathrm{N}$ & $\mathrm{N}$ & $\mathrm{N}$ & $\mathrm{N}$ & $\mathrm{N}$ & $\mathrm{N}$ & $\mathrm{N}$ & $\mathrm{Y}$ & $\mathrm{Y}$ & $\mathrm{N}$ & $\mathrm{N}$ \\
\hline Imported Grain & $\mathrm{Y}$ & $\mathrm{Y}$ & $\mathrm{Y}$ & $\mathrm{Y}$ & $\mathrm{Y}$ & $\mathrm{Y}$ & $\mathrm{Y}$ & $\mathrm{Y}$ & $\mathrm{N}$ & $\mathrm{N}$ & $\mathrm{N}$ & $\mathrm{N}$ \\
\hline Imported Supplement & $\mathrm{Y}$ & $\mathrm{Y}$ & $\mathrm{Y}$ & $\mathrm{Y}$ & $\mathrm{Y}$ & $\mathrm{Y}$ & $\mathrm{Y}$ & $\mathrm{Y}$ & $\mathrm{Y}$ & $\mathrm{Y}$ & $\mathrm{Y}$ & $\mathrm{Y}$ \\
\hline \multicolumn{13}{|l|}{ Density } \\
\hline AU/ Production ha & 1.17 & 2.11 & 1.27 & 1.50 & 2.18 & 1.01 & 2.82 & 0.67 & 1.73 & 1.81 & 1.85 & 1.35 \\
\hline AU/ Spreadable ha & 5.56 & 4.14 & 2.15 & 8.42 & 3.82 & 1.51 & 10.54 & 3.46 & 5.20 & 4.10 & 3.87 & 4.55 \\
\hline
\end{tabular}


Appendix E: West Virginia USDA NRCS Setback Criteria 


\begin{tabular}{|c|c|c|c|c|c|}
\hline \multicolumn{5}{|c|}{$\begin{array}{l}\text { WV NRCS COMPREHENSIVE NUTRIENT MANAGEMENT PLANNING AND NUTRIENT MANAGEMENT } \\
\text { (590) MANURE APPLICATION SETBACK DISTANCES }\end{array}$} & $\begin{array}{l}\text { Nutrient Management Setback } \\
\text { Worksheet 03/04/16 } \\
\text { Page 1/2 }\end{array}$ \\
\hline \multicolumn{6}{|c|}{$\begin{array}{l}\text { When applying organic "material" (animal manures, litter, composted animal mortalities (normal) or agricultural process wastewater) onto West Virginia's } \\
\text { undulating land or hillside slopes ( }<=30 \% \text { slope), heavy clay soils, karst or other landscape signatures, setback distances from these sensitive features or } \\
\text { areas is required. }\end{array}$} \\
\hline \multicolumn{6}{|c|}{ Sensitive Features are water wells, dwellings, property lines, roads or Tier 3 Streams in WW. } \\
\hline \multicolumn{6}{|c|}{$\begin{array}{l}\text { Sensitive Areas are surface water bodies, ponds, streams or creeks, springs or spring seeps, sinkholes, wetlands, open tile inlets, or direct links to surface } \\
\text { water. }\end{array}$} \\
\hline \multicolumn{6}{|c|}{$\begin{array}{l}\text { Sensitive features and areas must be identified in accordance with WV Conservation Practice Standard Nutrient Management (590). Material application } \\
\text { setbacks contained in Table } 1 \text { apply to Animal Feeding Operations, Concentrated Animal Feeding Operations and non-CAFO farms. However, if working } \\
\text { with a designated CAFO, adhere to WV DEP CAFO Permit requirements, when more stringent (see link below). }\end{array}$} \\
\hline \multicolumn{6}{|c|}{ TABLE 1} \\
\hline \multicolumn{5}{|c|}{ 1 A) Application of "Material" Setback Distance from Sensitive Feature(s) } & Setback Distance (Ft.) \\
\hline \multicolumn{5}{|c|}{ i) Agricultural Well (livestock, wildlife, irrigation and other agricultural purposes) } & 100 \\
\hline \multicolumn{5}{|l|}{ ii) Public, Commercial or Private Potable Well } & 200 \\
\hline \multicolumn{5}{|l|}{ iii) Occupied Dwelling' } & 100 \\
\hline \multicolumn{5}{|l|}{ iv) Property Line' or Public Road } & 20 \\
\hline \multicolumn{5}{|c|}{ v) WV Streams listed as DEP Tier 3 or outstanding national resource waters (http://dep.ww .gov/MWVE/Programs/wqs/Pages/default.aspx) } & 100 \\
\hline \multicolumn{6}{|c|}{1 may be applied closer with owner's and/or occupants permission } \\
\hline \multicolumn{6}{|c|}{1 B) "Material" is applied upslope of a minimum 35 foot wide Buffer ${ }^{2}$ that is adjacent to the sensitive area, otherwise reference 1C). } \\
\hline \multicolumn{6}{|c|}{$\begin{array}{l}1 \mathrm{C}) \text { "Material" application setback distance upgradient and adjacent to; surface water, ponds, streams or creek banks or springs or spring } \\
\text { seeps or edge of sinkhole, wetlands, open tile inlets or direct links to surface water when there is no } 35^{5} \text { Buffer }{ }^{2} \text { between the sensitive and land } \\
\text { apllication areas. }\end{array}$} \\
\hline \multirow{2}{*}{ Land Slope } & \multicolumn{2}{|c|}{ Material Application Method } & \multicolumn{2}{|c|}{ Vegetative Cover } & \multirow{2}{*}{$\begin{array}{l}\text { Minimum Application Setback } \\
\text { Distance (Ft.) }\end{array}$} \\
\hline & Surface Applied & $\begin{array}{c}\text { Injected or Incorporated } \\
\text { within } 48 \text { hours }\end{array}$ & $50 \%$ or greater & Less than $\mathbf{5 0} \%$ & \\
\hline \multicolumn{5}{|c|}{ When "material" is applied upslope of a minimum 35 foot wide Buffer ${ }^{2}$, no additional setback distan } & 35' Buffer \\
\hline \multirow{4}{*}{ Less than or equal to $12 \%$} & $\checkmark$ & & 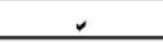 & & 50 \\
\hline & $\checkmark$ & & & $\checkmark$ & 70 \\
\hline & & $\checkmark$ & $\checkmark$ & & 35 \\
\hline & & $\checkmark$ & & $r$ & 50 \\
\hline \multirow{4}{*}{ Greater than $12 \%$} & $\checkmark$ & & $\checkmark$ & & 70 \\
\hline & $\checkmark$ & & & $\checkmark$ & 100 \\
\hline & & $\checkmark$ & $\checkmark$ & & 70 \\
\hline & & $\checkmark$ & & $\checkmark$ & 100 \\
\hline \multirow{4}{*}{$\begin{array}{l}\text { Setbacks from Surface Drainage Field } \\
\text { Ditches (designed to lower the water table) } \\
\text { located in Prior Converted Wetlands }\end{array}$} & $\checkmark$ & & $\checkmark$ & & 50 \\
\hline & $\checkmark$ & & & $\checkmark$ & 70 \\
\hline & & $\checkmark$ & $\checkmark$ & & 10 \\
\hline & & $\checkmark \mid$ & & $\checkmark$ & 20 \\
\hline \multicolumn{5}{|c|}{$\begin{array}{c}\text { Emergency Application onto Frozen or Snow Covered Ground; add 100' to the above setback distance and apply nutrients at a rate not to } \\
\text { exceed } 50 \% \text { of the annual recommendation. }\end{array}$} & $100^{\prime}+$ above setback distance \\
\hline \multicolumn{6}{|c|}{$\begin{array}{l}{ }^{2} \text { For "Buffer" planning guidance, reference WW NRCS Conservation Practice Standard Riparian Forest Buffer (CPS 391), Field Border (386), Filter Strip (393) or other approved } \\
\text { conservation practice. Vegetation or cover is well-established and maintained to facilitate fibrous, deep roots to maximize infiltration and nutrient uptake. Regardless of the field } \\
\text { characteristics, When a } 35 \text { foot or greater width buffer is established or present between the application field and the sensitive area and no "materials" are applied, it is defined as a } \\
\text { "Buffer". }{ }^{3} \text { Prior Converted Wetlands (prior to } 12 / 23 / 1985 \text { ) are where the hydrologic functions were altered allowing for crop production and in accordance with the Wetland } \\
\text { Conservation provision (Swampbuster) of the } 1985 \text { and } 1990 \text { farm bills. }\end{array}$} \\
\hline
\end{tabular}


Appendix F: Soil Sampling and Analysis 


\section{Soil Sampling Procedure}

Soil sampling is important to the data collection process and because multiple people will be taking samples, it crucial that all are following the same procedures and obtaining samples from the proper depth. For this research, Soil Science Society of America: Soil Testing and Plant Analysis will be used as technical reference.

\section{Management Sampling}

The first step to properly soil test a farm it to determine the areas that are to be sampled. For this research, sampling of fields is not performed at a field level exclusively, but rather to a level of management unit assigned by the farm operator. Management area sampling protocols will be followed for this aspect of the procedure, more information can be found in the reference text, under "Management Sampling”. This may be due to topographical differences, animal tendencies, or areas that are untreatable by the equipment which the farmer owns. For example, a 25-acre pasture field may only be mapped as a single unit, however the operator may prefer to split it into three sections for liming and fertilizing. In this case the field will be divided into section $\mathrm{A}, \mathrm{B}$, and $\mathrm{C}$ of the original field number.

\section{Number of Samples}

Number of samples needed is based on the size of the field that is being sampled. It is important that the sample is a representation of the entire field, so even smaller fields require multiple samples. As stated in the reference text, fields less than five acres, take 10 to 20 cores and fields between five and 10 acres, require 20 to 30 cores. In a case of a field that is larger than 10 acres, divide it into management areas, based on the strategies of the farmer. However, this does not mean that when the recommended number of samples is met, sampling stops. Above all else, it must be a complete sample with the best representation possible. This number will also be dependent on the amount of soil collected. At least one full sandwich bag is to be collected.

\section{Sampling Pattern}

Sampling pattern is also important to making sure that data is random and is an accurate representation of the land area. It is important to stay away from fence lines, watering areas, and anything that may seem abnormal to the overall appearance of the field, e.g. bare spots, areas of heavy loafing, or areas of extreme herbaceous pests, such as thistles or multifloura rose. Stay approximately 50 feet from all of the above mentioned areas, or anything else that pray appear to 
not be a normal part of the field. When walking fields to obtain samples, a random pattern must be used to be sure a sample is accurate and representative.

\section{Sampling Depth}

Depth of sample is key to having truly comparable data. When entering a field to sample, the management and tillage practices of that field must be known. Because of nutrient incorporation differences, hay and pasture have a different depth than a tilled crop field. When hay and pasture are sampled a core of two inches is taken, while when sampling tilled crop ground a core is taken to a depth of six inches. No-till crop fields should be double sampled at a depth of one inch and at six inches. A mark or a piece of tape around the soil probe provides a gauge for depth. Also, taking a larger sample and only using the top two or six inches is also acceptable. More information on this topic is in the text as "Sample to the Proper Depth."

\section{After Collection}

When in the field the samples will be numbered by tract and field number. Once you return to the office and prepare the samples for mailing, you can name them whatever you want, as long as you, the farmer, and I have a copy of your naming system. I would suggest the farmers name as you have written it within your Excel sheet. Half of the sample will be sent to the WVU Soil Testing Lab. Since these will be shipped directly from you to the lap, use your judgment about when to send samples. If you will be in the area, they can be hand delivered. If not, you will UPS the samples to the lap. Setting up a UPS shipment is shown in the paper of shipping. The remaining half will be saved and returned to me at the university 
WEST VIRGINIA UNIVERSITY SOIL TESTING LABORATORY

P.O. Box 6108, MORGANTOWN, WV 26506-6108
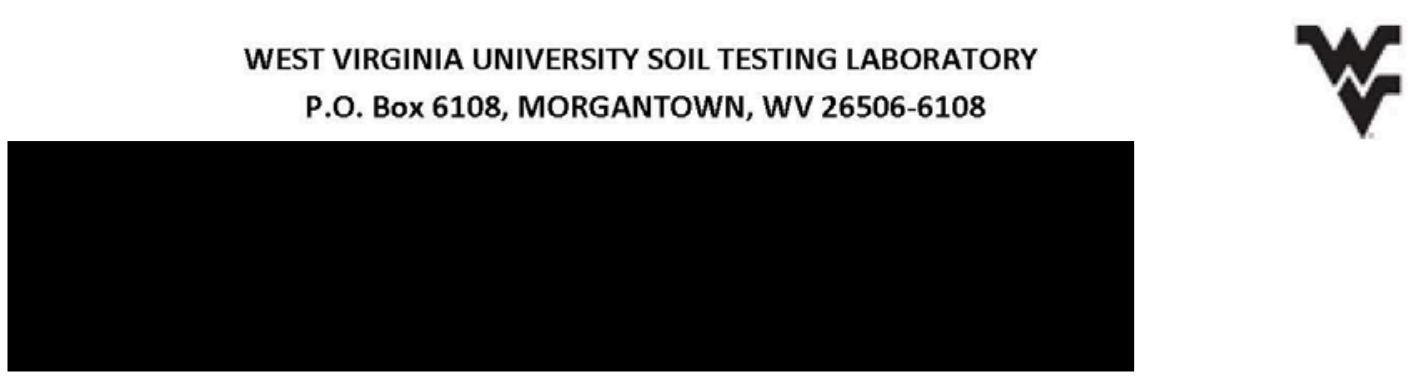

SAMPLE DETAILS Sample ID: FIELD 6

\begin{tabular}{|l|l|l|l|}
\hline Sample Date & $12 / 16 / 2015$ & Previous Crop & HAY/PASTURE \\
\hline LAB ID & $16-19$ & Soil Name & DORMONT/CULLEOKA \\
\hline Limed in last 12Months & No & Soil Texture & Silty Loam \\
\hline Area (Acre) & 10 & Tillage Method & No-Till \\
\hline
\end{tabular}

\section{LAB TEST RESULTS}

Nutrients Values Rating

\begin{tabular}{lll|l|l|l|l|} 
Soil pH & 5.8 & L.R.: 1.3 & LOW & MEDIUM & HIGH & V HIGH \\
P2O5(Lbs/A) & 70 & HIGH & P2O5 & & &
\end{tabular}

$\begin{array}{lcc}\text { K2O(Lbs/A) } & 112 & \text { MEDIUM } \\ \text { Ca(Lbs/A) } & 3162 & \text { HIGH } \\ \text { Mg(Lbs/A) } & 459 & \text { HIGH }\end{array}$
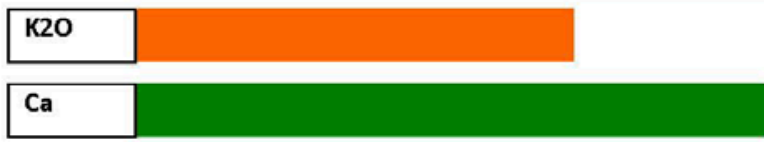

$\mathrm{Mg}$

\begin{tabular}{|l|l|l|l|l|l|}
\hline Nutrients & $\mathrm{K}$ & $\mathrm{Ca}$ & $\mathrm{Mg}$ & $\mathrm{H}$ & Total[CEC], BS(K+Ca+Mg) \\
\hline MEQ/100 & 0 & 8 & 2 & 3 & 13 \\
\hline \%Sat & 2 & 63 & 16 & 21 & 81 \\
\hline
\end{tabular}

RECOMMENDATIONS FOR CROP: TALL GRASS HAY OR PASTURE (Less than 30\% legume)

\begin{tabular}{|l|l|}
\hline Aglime & 2 T/A GROUND LIME \\
\hline Fertilizer - N (Lbs/Acre) & $50-200$ \\
\hline Fertilizer - P2O5 (Lbs/Acre) & 40 \\
\hline Fertilizer - K2O (Lbs/Acre) & 120 \\
\hline
\end{tabular}

\section{SUGGESTIONS}

The above recommendations are for a yield goal of 3 to 4 Tons/Acre and assume a soil pH corrected to 6.5 .

$\mathrm{N}$ needs depend on desired yield goal. $\mathrm{K}$ application should be reduced if magnesium (Mg) is low (less than $100 \mathrm{Lbs} / \mathrm{A}$ ).

Use any fertilizer or approved organic material that will supply the plant nutrients recommended. Your county agent can suggest

locally available fertilizers to suit the recommendation. Apply $50 \mathrm{Lbs} / \mathrm{A}$ of $\mathrm{N}$ by itself or with a complete fertilizer in late winter and/or September. An additional 50 Lbs/A of $\mathrm{N}$ can be applied after the first cutting if desired. Retest your soil each fall. 
Appendix G: Manure Sampling and Analysis 


\section{Manure Sampling:}

Limited manure sampling will be done by interns due of the time of the year that you will be placed., however you may have to do some. When sampling manure, much like soils or forages, it is important to have a representative sample. Depending on type of manure storage, sample method will change. For my research, you will be sampling dry stack manure in a WSF, but if manure is imported, it will need sampled also. Manure sampling will follow techniques described by (Rutgers Cooperative Research \& Extension, 2006)

\section{Stacked Manure:}

This may be beef manure from a roofed winter feeding area, or could be poultry litter being imported. Manure samples should not be taken from the outside of the pile, rather the internal where the manure is not oxidized. With a shovel, dig into the pile at least $40 \mathrm{~cm}$ in at least five different areas. Manure in a pile should have at least one sub-sample from each face. Once you have dug into the pile remove a sample and place the sub-sample in a clean sampling bucket. Take a sample from each opening and mix them together. Once the manure is mixed, fill a manure sample bottle 2/3rd full. Label the top of the container with a sample number and cooperators name and then put it in a zippered sandwich bag. Manure samples must be kept cool, so make manure samples one of your last jobs for the day. Once back to the office, refrigerate the sample until it is mailed. To mail the samples, follow the procedure in the UPS shipping guide. With the remaining mixed sample, collect a sandwich bag and freeze it. You will return this to West Virginia University for other tests.

\section{Slurry:}

To accurately sample a slurry tank, the sample needs to be done while it is being agitated. This ensures that the solids from the bottom are mixed with the liquid from the top, as it would when it's applied. Slurry samples can be taken by collecting a manure bottle 2/3 full from any place, or multiples. Since the manure is being agitated when you sample, we can assume that it will be uniform throughout. Also, take 2/3rd of a sample bottle and freeze it for other testing.

\section{Notes:}

**Sample manure early in the week and mail them no later than Wednesday so they do not sit in the mail over the weekend.

**Try to avoid as much direct contact with manure as possible. Your offices may have boot covers to use as a bio security measure. 


\section{(6) \\ State of West Virginia \\ DEPARTMENT OF AGRICULTURE}

Walt Helmick, Commissioner

\section{LABORATORY ANALYSIS REPORT}

WVDA Nutrient Management T.ab

Moorefield Field Office

60B Industrial Park Road

Mooreficld, WV 26836

304-538-2397

\author{
Date Received: March 08, 2016 \\ Date Sampled: March 05, 2016 \\ Date of Report: March 15, 2016
}

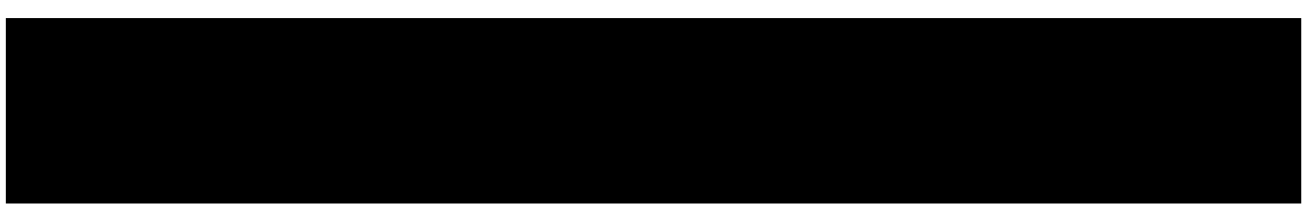

Sample ID Number:

A.A 10442

Sample Description:

Semi-solid Beef (sample 2)

\begin{tabular}{|c|c|c|c|c|c|}
\hline lest Parameter & $\mathrm{lbs} /$ ton & $\%$ & Test date & Method & MDL \\
\hline (N)Nitrogen (TKN) & 13.2 & 0.659 & $03 / 15 / 2016$ & SM 4500-NH3 C. & 0.153 \\
\hline (P)Phosphate (P2O5) & 5.72 & 0.286 & $03 / 15 / 2016$ & $\mathrm{EP} \wedge 200.7$ & 0.002 \\
\hline (K)Potassium (K2O) & 16.5 & 0.827 & $03 / 15 / 2016$ & FPA 200.7 & 0.012 \\
\hline Moisture & & 74.4 & $03 / 15 / 2016$ & SM 2540 B. & 0.088 \\
\hline Ammonium & 2.46 & 0.123 & $03 / 15 / 2016$ & SM $4500-\mathrm{NII} 3 \mathrm{G}$. & 0.002 \\
\hline C:N Ratio & 43.7 & & $03 / 15 / 2016$ & & \\
\hline Copper & 0.00988 & 0.000494 & $03 / 15 / 2016$ & $\mathrm{LP} A 200.7$ & 0.001 \\
\hline Calcium & 4.15 & 0.208 & $03 / 15 / 2016$ & EPA 200.7 & 0.001 \\
\hline Magnesium & 2.40 & 0.120 & $03 / 15 / 2016$ & EPA 200.7 & 0.002 \\
\hline pII & & 8.21 & $03 / 15 / 2016$ & SW-846 9045D & \\
\hline
\end{tabular}

"Calculations based on Total Solids measurement

When surface applied this sample will supply plant available:

$\begin{array}{lll}\text { Nitrogen (N) (Surface available) } & 4.98 & \mathrm{lbs} / \mathrm{ton} \\ \text { Nitrogen (N) (Incorporated) } & 5.96 & \mathrm{lbs} / \text { ton } \\ \text { Phosphate (P2O5) } & 5.72 & \mathrm{lbs} / \mathrm{ton} \\ \text { Potash (K2O) } & 16.5 & \mathrm{lbs} / \mathrm{ton}\end{array}$

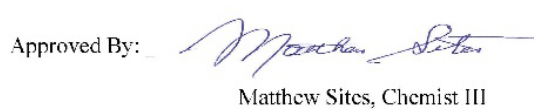

60B Moorefield Industrial Park Road • Moorefield, West Virginia 26836-9737 • 304/538-2397 • www.wvagriculture.org

"The Basis of All Wealth is Agriculture" 
Appendix H: Feed Sampling and Analysis 


\section{Feed Sampling:}

Feed samples are used to determine the amount of phosphorous, $\mathrm{P}$, being removed in crop harvested on the farm, and also to determine imported P. Grains, minerals, supplements, hays, and silages must all be sampled to have an accurate representation. Each sample, needs to be at least one zippered sandwich bag which can be divided. One half bag of sample will be mailed from the student intern directly to Cumberland Valley Analytical Service, CVAS for analysis (for mailing, refer to CVAS sample information). Half of a bag is to be saved and returned to West Virginia University for additional testing. If it is a wet sample (silage) store it in the freezer. Forage and Grain sampling follow the protocol by (Undersander et al., 2005)

\section{Forage (Hay)}

After meeting your farmer and during visits, ask for a projected time for their forage removal. Forage samples need to be taken when the hay is in the field, rather than once it has been put in the barn. This will ensure that the number of bales is accurate and that there is no mixing of fields. Forage samples must be taken from each field, and cut throughout the year. Once the hay is baled, you may begin the sampling process. Start by removing the plunger and attaching a sample bag to the bottom of the Star Quality Forage Probe. For round bales, push your probe into the rounded side of the bale, trying to hit as close to the center of the bale as possible. For square bales, sample from the end of the bale, and not the side. Take at least 20 cores per field per cut. In the case of extremely large fields, take more samples. You must use your judgment as to what you think shows representation, but always sample more than what is needed. This may result of testing a bale multiple times, which is acceptable. Once the cores are taken, transfer the forage sample to a zippered sandwich bag with the operation name, sample ID number, field, and date. After the sample is taken, make the proper notes for the cut, number of bales, and estimated weight. Weight can be estimated with the dimensions of the bale.

\section{Forage (Silage)}

Since corn silage is chopped in the fall, you will likely not need to sample this. If silage is still present on the farm, the process is much like manure sampling. Take multiple samples from within the pile and mix them together, taking a small sample of the mixture. You will only use a bag, a shovel, and a bucket for this process. To sample wrapped bales, use the probe as instructed 
in round bale hay sampling. Also as with hay, take at least 20 cores. After the sample is taken, use a rag and wipe the plastic off and apply patch tape. It is vital that the hole be covered, so use whatever is necessary. It is important to understand that any air in the bales, will cause the hay to rot, so make sure it is patched properly. The quality of the forage will change over the ensiling process, the phosphorous content will not. Another sample will be taken for forage quality in the fall before feeding. When note taking for wrapped hay, follow the same guide as hay. For silage, note the tons harvested. These samples need to be kept cool, so store them in the refrigerator, and mail early in the week.

\section{Grain/Supplement}

Grain and supplements are a grab sample. Take a small handful of what you are sampling in a zippered sandwich bag. Make notes of the ID of the sample, number of bags purchased, and weight of bags. In the case of bulk tanks, recorded tons received. 


\section{Cumberland Valley Analytical Services}

Laboratory services for agriculture ... from the field to the feed bunk.

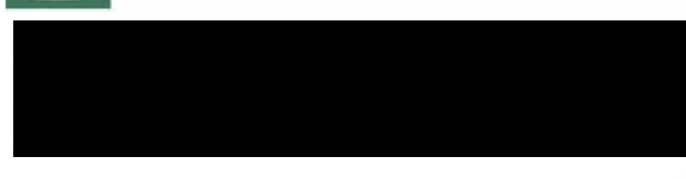

\section{WRAPPED $11 B$}

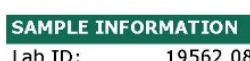

Lab ID: $\quad 1956208$

Crop Year: 2015

Feed Type: MMG FORAGE

Package: NIR Wet Minerals

NIR ANALYSIS RESULTS

Moisture

Dry Matter

\section{PROTEINS}

Crude Protein

Adjusted Protein

Soluble Protein

Ammonia (CPE)

ADF Protein (ADICP)

NDF Protein (NDICP)

NDR Protein (NDRCP)

Rumen Degr. Protein

Rumen Deg. CP (Strep.G)

$\begin{array}{lrr}\text { FIBER } & \text { \% NDF } & \% \text { DM } \\ \text { ADF } & 62.7 & 36.3 \\ \text { aNDF } & & 57.9 \\ \text { aNDFom } & & 56.0 \\ \text { NDR (NDF w/o sulfite) } & & \end{array}$

NDR (NDF w/o sulfite)

peNDF

Crude Fiber

Lignin

NDF Digestibility ( $12 \mathrm{hr}$ )

NDF Digestibility (24 hr)

NDF Digestibility $(30 \mathrm{hr})$

NDF Digestibility (48 hr)

NDF Digestibility $(120 \mathrm{hr})$

NDF Digestibility ( $240 \mathrm{hr}$ )

UNDF (30 hr)

UNDF (120 hr)

UNDF $(240 \mathrm{hr})$

\section{CARBOHYDRATES}

Silage Acids

Ethanol Soluble $\mathrm{CHO}$ (Sugar)

Water Soluble CHO (Sugar)

Starch

Soluble Fiber

Starch Dig. (7 hr, $4 \mathrm{~mm}$ )

Fatty Acids, Total

Fatty Acids (\%Fat)

Crude Fat

Values in bold were analyzed by wet chemistry methods. Definitions and explanation of report terms
Lab ID:

Sampled:

19562088

Arrived:

$01 / 09 / 2016$

Completed: $01 / 18 / 2016$

Reported: $01 / 18 / 2016$

MINERALS

Ash (\%DM)

Calcium (\%DM)

7.61

Phosphorus (\%DM)

0.64

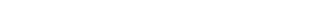

Potassium (\%DM)

Sulfur (\%DM)

Sodium (\%DM)

2.33
0.21

Chloride (\%DM)

Iron (PPM)

Manganese (PPM)

Zinc (PPM)

Copper (PPM)

Nitrate Ion (\%DM)

Selenium (PPM)

Molybdenum (PPM)

ENERGY \& INDEX CALCULATIONS
pH

TDN (\%DM)

Net Energy Lactation (mcal//b)

Net Energy Maintenance (mcal/lb) $\quad 0.61$

Net Energy Gain (mcal/lb)

NDF Dig. Rate (Kd, \%HR, Van Amburgh, Lignin*2.4)

$8.815 .10 \quad$ NDF Dig. Rate (Kd, \%HR, UNDF)

Starch Dig. Rate (Kd, \%HR, Mertens)

Relative Feed Value (RFV)

Relative Feed Quality (RFQ)

Milk per Ton (lbs/ton)

Dig. Organic Matter Index (lbs/ton)

Non Fiber Carbohydrates (\%DM)

Non Structural Carbohydrates (\%DM)

DCAD (meq/100gdm)

CNCPS / CPM Lignin Factor

Summative Index \% (Mass Balance)

Additional sample information, source and lab

pictures 
Appendix I: Estimating $P$ concentration in Calves 


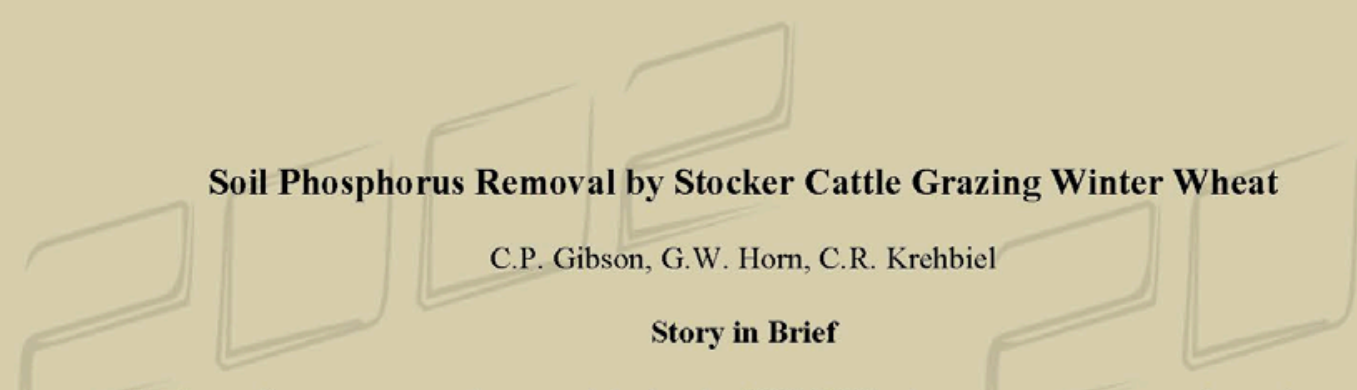

Six Santa-Cruz steers were harvested during the 2000/2001 wheat pasture season to determine phosphorus accretion of stocker cattle grazing winter wheat pasture. Phosphorus concentration of carcass and offal was determined and phosphorus accretion in carcass, offal, empty body, and live weight was determined by simple linear regression. Phosphorus accretion $(\mathrm{g} / \mathrm{kg})$ of carcass, empty body, and live weight was 7.5, 6.4, and 7.1, respectively. Phosphorus accretion $(\mathrm{g} / \mathrm{kg})$ of carcass and empty body protein was 32.6 and 26.7 , respectively. Overall soil phosphorus removal by cattle is influenced by total weight gained, and is substantially less than phosphorus removed by forage biomass.

Key Words: Steers, Phosphorus, Carcass, Empty body, Live weight

\section{Introduction}

The primary method of soil phosphorus removal is by harvesting grain or forage crops. Another way that phosphorus can be removed is by grazing cattle. In order to determine the amount of phosphorus removed by winter wheat, phosphorus removal via wheat grain, hay, and grazing must be quantified. The data reported herein was obtained as part of a larger five-treatment study that was conducted to determine the amount of soil phosphorus removed in grain, hay, and grazing. Treatments included: 1) grazing during the winter, followed by grazing in the spring; 2) grazing during the winter, forage harvested as hay in the spring; 3) grazing during the winter, grain harvested in the spring; 4) no winter grazing, forage harvested as hay in the spring; and 5) no winter grazing, grain harvested in the spring. The objective of this study was to quantify the amount of phosphorus that is removed from soil as a result of winter grazing of stocker cattle on wheat pasture.

\section{Materials and Methods}

Six Santa Cruz steers were randomly selected from a group of steers used for another study. Three steers were harvested at the Oklahoma Food and Agricultural Products Research and Technology Center (FAPC) on January 15, 2001, prior to grazing wheat pasture, to determine initial phosphorus concentration in the whole body. Live weights of these steers were measured on January 10, when the steers were being withheld from feed and water. Steers that remained were introduced to pastures on January 10 until March 21, 2001 (winter grazing period, $70 \mathrm{~d}$ ), and from March 21 to April 11 (grazeout period, $21 \mathrm{~d}$ ). During the winter period, eight to 12 steers were assigned to each of four pastures ( 2.1 acres/steer), and during the grazeout period, stocking density was adjusted to eight to 14 steers in each pasture (.70 acres/steer). Three steers were harvested following completion of the grazeout period on April 16, to determine final phosphorus concentration in the whole body. Live weights of this group were measured on April 11 following an overnight shrink (approximately 16 hours) without feed or water.
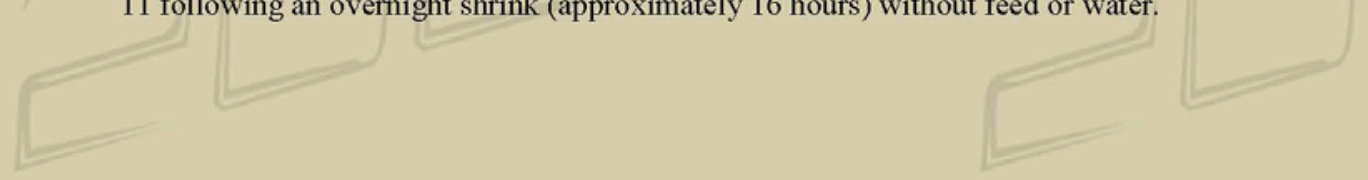
Steers were harvested following normal operating procedures for FAPC. Once the steers were eviscerated, the visceral organs were removed, cleaned of their contents, and weighed individually. In addition to organs, head, hide, blood, mesenteric fat, and feet and ears were weighed. These weights were combined to determine total offal weight for each steer.

Offal was ground in a whole body grinder on the day of harvest. The right side of each carcass was ground in the same grinder following a 24-h chill. Triplicate samples, about $10 \mathrm{lb}$ each, were collected from carcass and offal. Sub samples were collected to be lyophilized, and finely ground for subsequent laboratory analysis to determine nitrogen and phosphorus concentration. Samples were digested in $25 \% \mathrm{HCl}$, and analyzed spectrophotometrically to determine phosphorus concentration. Phosphorus concentration was then used to determine total phosphorus ( $\mathrm{g} \mathrm{DM})$ in carcass and offal. Total phosphorus gain $(\mathrm{g} / \mathrm{kg})$ in carcass, empty body, and live weight was determined using simple linear regression analysis.

Nitrogen concentration was determined using a total combustion technique (NS-2000 ; LECO, St. Joseph, MI). Nitrogen concentration was used to compute percent crude protein in carcass and offal, by multiplying percent nitrogen $\times 6.25$. Phosphorus accretion per $\mathrm{kg}$ of protein in carcass and total empty body was determined by regression of total phosphorus (g) against total protein $(\mathrm{kg})$ in carcass, and empty body.

\section{Results and Discussion}

Mean daily gain of the three steers harvested on April 16 was $.90,3.21$, and $1.44 \mathrm{lb}$ for winter, grazeout, and the overall trial (91 d), respectively. Phosphorus accretion in carcass, empty body, and live weight was 7.5, 6.4, and $7.1 \mathrm{~g} / \mathrm{kg}$ and is shown graphically in Figures 1, 2, and 3, respectively. Phosphorus accretion in this study was within the range of 5 to $8 \mathrm{~g} \mathrm{P} / \mathrm{kg}$ live weight in pigs reported by Jongbloed (1987). Phosphorus concentrations in beef and swine tissue are similar (Anderson and Hoke, 1990; Anderson et al., 1992), and therefore, phosphorus accretion rates in cattle should be similar to that of the pig.

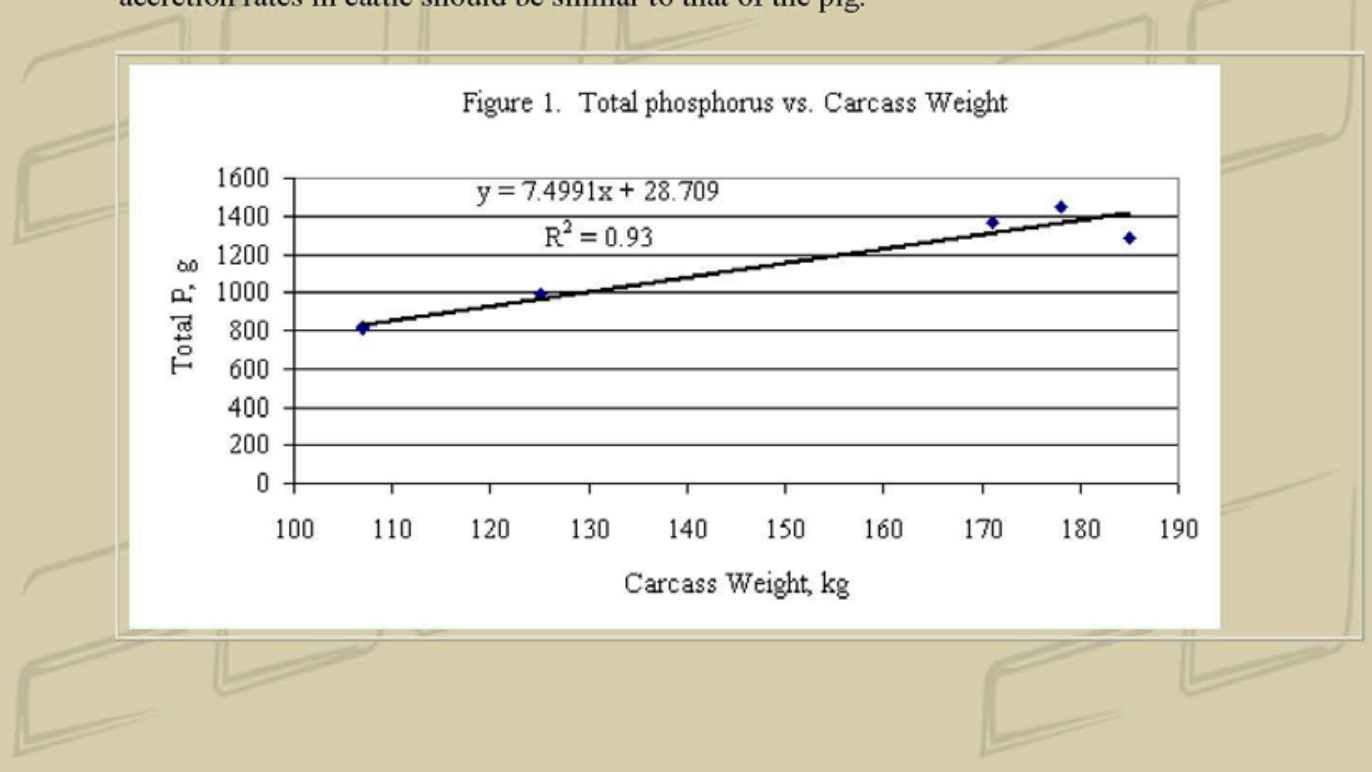

Figure 1. Total phosphorus vs. Carcass Weight 


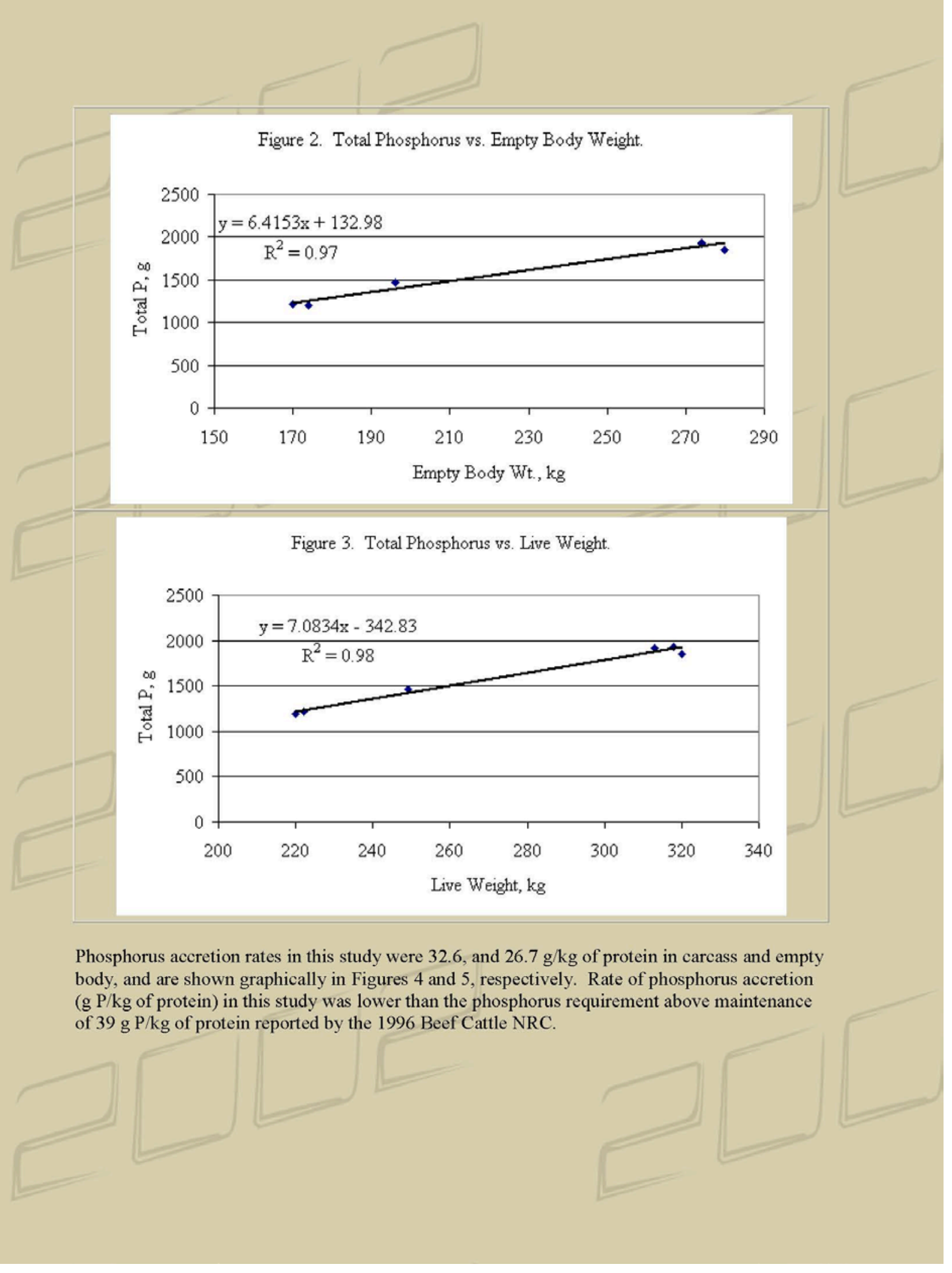




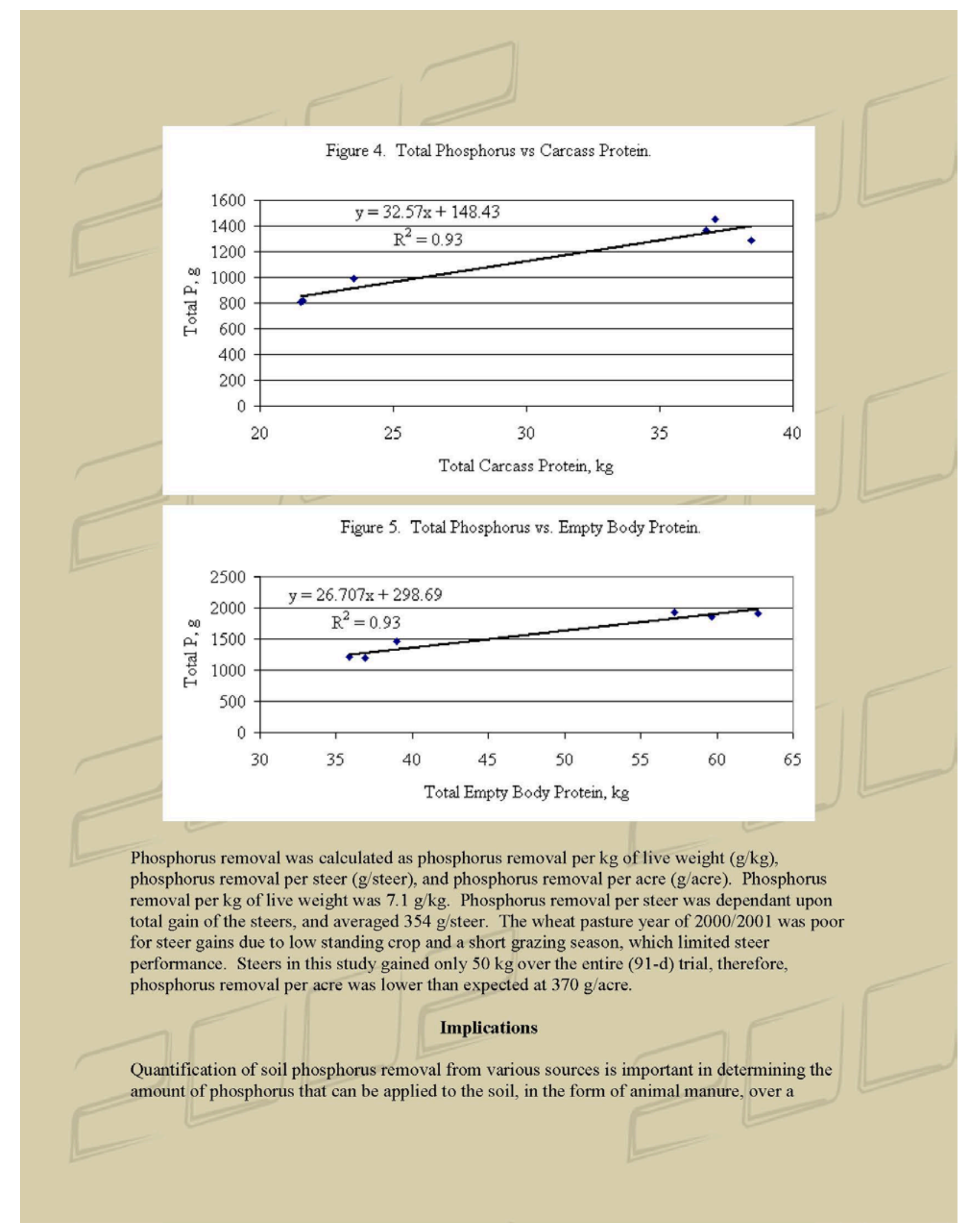


specific area. In the current study, the greatest amount of soil phosphorus was removed by forage biomass. At the Marshall location, $6,595 \mathrm{~g} \mathrm{P} /$ acre was removed by harvesting the forage as hay, and 4,926 g P/acre was removed by harvesting grain. This is substantially greater than the amount of phosphorus removed by grazing cattle ( $370 \mathrm{~g} / \mathrm{acre})$.

\section{Literature Cited}

Anderson, B.A. and I.M. Hoke. 1990. USDA Human Nutr. Info. Service. Ag. Handbook No. 813.

Anderson, B.A. et al. 1992. USDA Human Nutr. Info. Service. Ag. Handbook No. 8-10.

Jongbloed, A.W. 1987. Phosphorus in the Body of Pigs.

NRC. 1996. Nutrient Requirements of Beef Cattle ( $7^{\text {th }}$ Ed.). National Academy Press, Washington, D.C.

Copyright 2002 Oklahoma Agricultural Experiment Station

[ 2002 Animal Science Research Reports $\mid$ Animal Science Research Reports $\mid$ Department of Animal Science ]
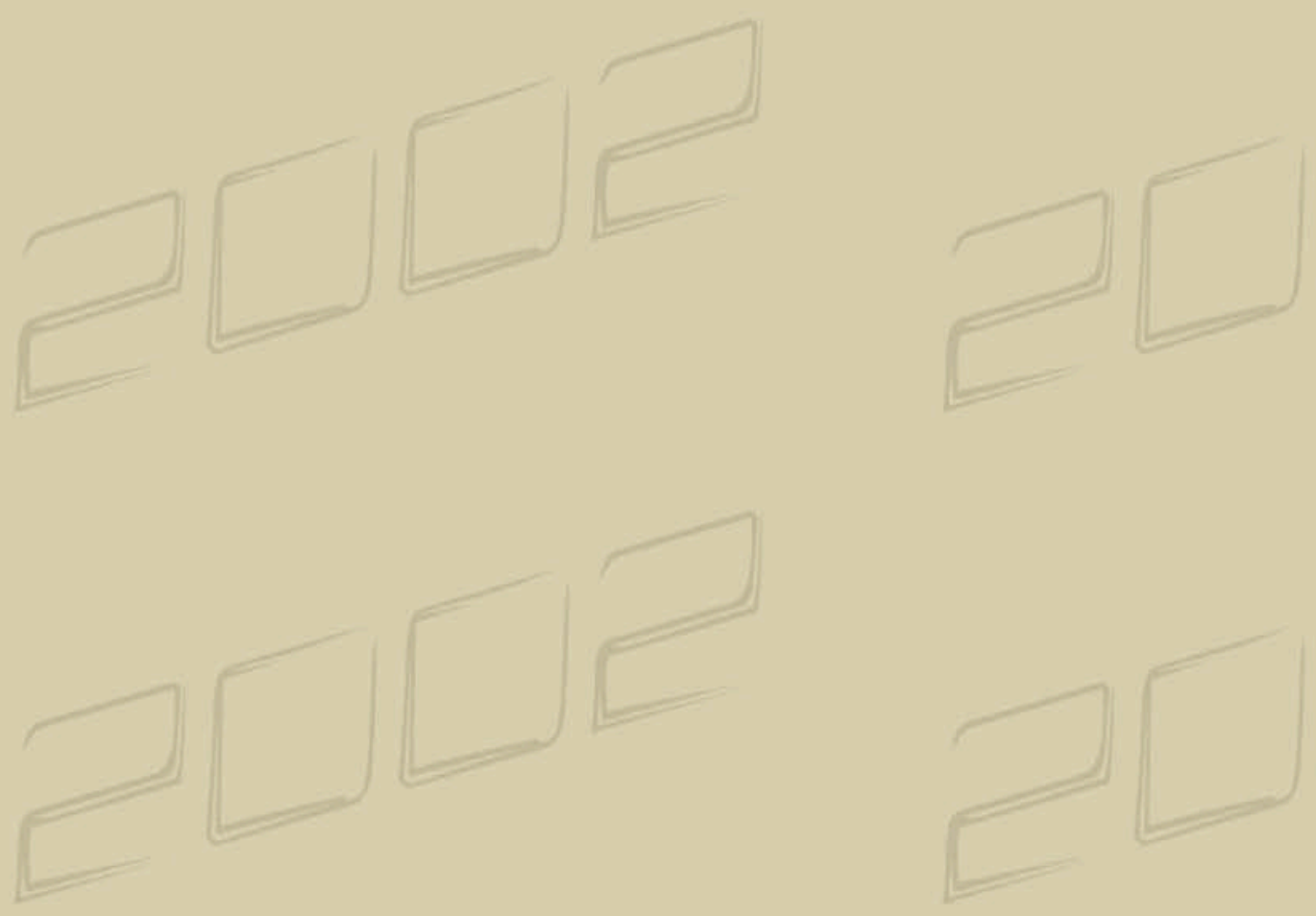
Appendix J: Raw Data for Whole Farm Nutrient Mass Balance 
Total Imported Hay (lbs)

Hay DM \%

Hay DM (lbs)

Hay $[\mathrm{P}](\% \mathrm{DM})$

Hay [P] (lbs)

Hay [P] (kg)

\begin{tabular}{|c|c|c|c|c|}
\hline \multicolumn{5}{|c|}{ Farms } \\
\hline \multicolumn{3}{|c|}{ Basic } & \multicolumn{2}{|c|}{ Complex } \\
\hline F1 & F2 & F3 & F4 & F5 \\
\hline \multicolumn{5}{|c|}{ Hay } \\
\hline 0 & 60,000 & 40,000 & 0 & 0 \\
\hline 0 & 0.87 & 0.75 & 0 & 0 \\
\hline 0 & 52,200 & 30,000 & 0 & 0 \\
\hline 0 & 0.0028 & 0.0023 & 0 & 0 \\
\hline $\mathbf{0}$ & 146.2 & 69.0 & $\mathbf{0}$ & $\mathbf{0}$ \\
\hline $\mathbf{0}$ & 66.3 & 31.3 & $\mathbf{0}$ & $\mathbf{0}$ \\
\hline
\end{tabular}

Grain/Supplement Imported (lbs)

Supplement DM \%

Supplement DM (lbs)

Supplemental [P] (\% DM)

Total Supplement [P] (lbs)

Grain/Supplement Imported (lbs)

Supplement DM \%

Supplement DM (lbs)

Supplemental [P] (\% DM)

Total Supplement [P] (lbs)

Total Supplement [P] (lbs)

Total Supplement [P] (kg)

Mineral (loose) (lbs)

Mineral DM \%

Mineral DM (lbs)

Mineral [P] (\% DM)

Loose Mineral [P] (lbs)

Mineral (Tub) (lbs)

Mineral DM \%

Mineral DM (lbs)

Mineral [P] (\% DM)

Tub Mineral [P] (lbs)

Total Mineral [P] (lbs)

Total Mineral [P] (kg)

Grain/Supplement

$\begin{array}{ccccc}32,000 & 0 & 15,000 & 15,000 & 36,000 \\ 0.857 & 0 & 0.87 & 0.87 & 0.884 \\ 27,424 & 0 & 13,050 & 13,050 & 31,824 \\ 0.007 & 0 & 0.0075 & 0.0075 & 0.009 \\ 200.2 & 0 & 97.9 & 97.9 & 286.4 \\ 0 & 0 & 3,000 & 3,000 & 0 \\ 0 & 0 & 0.859 & 0.859 & 0 \\ 0 & 0 & 2,577 & 2,577 & 0 \\ 0 & 0 & 0.0046 & 0.0046 & 0 \\ 0 & 0 & 11.9 & 11.9 & 0 \\ 200.2 & 0 & 109.7 & 109.7 & 286.4 \\ 90.8 & 0 & 56.2 & 56.2 & 129.9 \\ & & & & \\ 2,000 & 200 & 1,450 & 1,450 & 3,000 \\ 0.94 & 0.93 & 0.98 & 0.98 & 0.93 \\ 1,876 & 186.6 & 1,422.5 & 1,422.5 & 2,799 \\ 0.0840 & 0.0699 & 0.0476 & 0.0476 & 0.0699 \\ 157.6 & 13.0 & 67.7 & 67.7 & 195.6 \\ 2,000 & 1,600 & 2,000 & 0 & 1,500 \\ 0.70 & 0.67 & 0.90 & 0 & 0.56 \\ 1,400 & 1,065.6 & 1,782 & 0 & 846.375 \\ 0.0926 & 0.0072 & 0.0128 & 0 & 0.0699 \\ 129.6 & 7.7 & 22.8 & 0.0 & 59.2 \\ \mathbf{2 8 7 . 2} & \mathbf{2 0 . 7} & \mathbf{9 0 . 5} & \mathbf{6 7 . 7} & \mathbf{2 5 4 . 8} \\ \mathbf{1 3 0 . 3} & \mathbf{9 . 4} & \mathbf{4 1 . 1} & \mathbf{3 0 . 7} & \mathbf{1 1 5 . 6}\end{array}$


Fertilizer (lbs)

Fertilizer \% P2O5

Fertilizer P2O5 (lbs)

Fertilizer $\mathbf{P}$ (lbs)

Fertilizer $\mathbf{P}$ (kg)

Collected Mass (tons)

[P2O5]/ton

[P]/ton

Total Manure P (lbs)

Total Manure P (kg)

Total Imported P (lbs)

Total Imported P (kg)
Commercial Fertilizer

\begin{tabular}{ccccc}
\hline $1,152.8$ & 380 & 0 & $2,774.2$ & 0 \\
0.46 & 0.46 & 0 & 0.46 & 0 \\
530.3 & 174.8 & 0 & $1,276.1$ & 0 \\
$\mathbf{2 3 1 . 4}$ & $\mathbf{7 6 . 3}$ & $\mathbf{0}$ & $\mathbf{5 5 6 . 9}$ & $\mathbf{0}$ \\
$\mathbf{1 0 5 . 0}$ & $\mathbf{3 4 . 6}$ & $\mathbf{0}$ & $\mathbf{2 5 2 . 6}$ & $\mathbf{0}$ \\
& \multicolumn{5}{c}{ Manure } \\
\multicolumn{5}{c}{0} \\
0 & 0 & 0 & 0 & 40.0 \\
0 & 0 & 0 & 0 & 92.6 \\
$\mathbf{0}$ & 0 & 0 & 0 & 40.4 \\
$\mathbf{0}$ & $\mathbf{0}$ & $\mathbf{0}$ & $\mathbf{0}$ & $\mathbf{1 , 6 1 6 . 4}$ \\
$\mathbf{7 1 8 . 8}$ & $\mathbf{2 4 3 . 2}$ & $\mathbf{2 5 7 . 4}$ & $\mathbf{7 2 2 . 5}$ & $\mathbf{2 , 1 5 7 . 7}$ \\
$\mathbf{3 2 6 . 1}$ & $\mathbf{1 1 0 . 3}$ & $\mathbf{1 2 8 . 6}$ & $\mathbf{3 3 9 . 6}$ & $\mathbf{9 7 8 . 7}$
\end{tabular}


Total Exported Hay (lbs)

Hay DM \%

Hay DM (lbs)

Hay P (\% DM)

Hay $P$ (lbs)

Hay P (kg)

Head

AVG Weight (lbs)

AVG Weight (kg)

$\mathrm{g} \mathrm{P} / \mathrm{calf}$

kg P/calf

Total Livestock P (lbs)

Total Livestock P (kg)

Total Exported P (lbs)

Total Exported P (kg)

\begin{tabular}{ccccc} 
& \multicolumn{3}{c}{ Farms } & \multicolumn{2}{c}{ Complex } \\
\hline F1 & B2 & F3 & F4 & F5 \\
\hline & & Hay & & \\
\hline 80,000 & 6,000 & 0 & 40,000 & 0 \\
0.858 & 0.87 & 0.838 & 0.75 & 0.834 \\
68,640 & 5,220 & 0 & 30,000 & 0 \\
0.0031 & 0.0028 & 0.0019 & 0.0022 & 0.0031 \\
$\mathbf{2 1 2 . 8}$ & $\mathbf{1 4 . 6}$ & $\mathbf{0}$ & $\mathbf{6 6 . 0}$ & $\mathbf{0}$ \\
$\mathbf{9 6 . 5}$ & $\mathbf{6 . 6}$ & $\mathbf{0}$ & $\mathbf{2 9 . 9}$ & $\mathbf{0}$
\end{tabular}

Livestock

\begin{tabular}{ccccc}
\hline 39 & 20 & 16 & 16 & 25 \\
550 & 550 & 625 & 625 & 550 \\
249 & 249 & 283 & 283 & 249 \\
$1,424.3$ & $1,424.3$ & $1,665.3$ & $1,665.3$ & $1,424.3$ \\
$\mathbf{1 . 4}$ & $\mathbf{1 . 4}$ & $\mathbf{1 . 7}$ & $\mathbf{1 . 7}$ & $\mathbf{1 . 4}$ \\
$\mathbf{1 2 2 . 6}$ & $\mathbf{6 2 . 8}$ & $\mathbf{5 8 . 6}$ & $\mathbf{5 8 . 6}$ & $\mathbf{7 8 . 5}$ \\
$\mathbf{5 5 . 6}$ & $\mathbf{2 8 . 5}$ & $\mathbf{2 6 . 6}$ & $\mathbf{2 6 . 6}$ & $\mathbf{3 5 . 6}$ \\
& & & & \\
$\mathbf{3 3 5 . 4}$ & $\mathbf{7 7 . 4}$ & $\mathbf{5 8 . 6}$ & $\mathbf{1 2 4 . 6}$ & $\mathbf{7 8 . 5}$ \\
$\mathbf{1 5 2 . 1}$ & $\mathbf{3 5 . 1}$ & $\mathbf{2 6 . 6}$ & $\mathbf{5 6 . 5}$ & $\mathbf{3 5 . 6}$ \\
\hline
\end{tabular}


Raw Data for Collected Manure P

\begin{tabular}{lccccc}
\hline & \multicolumn{3}{c}{ Farms } \\
\cline { 2 - 6 } & \multicolumn{3}{c}{ Basic } & \multicolumn{3}{c}{ Complex } \\
\cline { 2 - 6 } Collected Mass (tons) & $\mathrm{F} 1$ & $\mathrm{~F} 2$ & $\mathrm{~F} 3$ & $\mathrm{~F} 4$ & $\mathrm{~F} 5$ \\
\cline { 2 - 6 } Collected Mass (Mt) & 250.0 & 72.0 & 138.0 & 142.0 & 136.0 \\
$\mathrm{P}_{2} \mathrm{O}_{5} / \mathrm{ton}$ & 226.8 & 65.3 & 125.2 & 128.8 & 123.4 \\
$\mathrm{P} / \mathrm{ton}$ & 5.21 & 5.37 & 5.06 & 5.89 & 19.44 \\
$\mathrm{~kg} / \mathrm{Mt}$ & 2.27 & 2.34 & 2.21 & 2.57 & 8.48 \\
Total Manure [P] (lbs) & 1.14 & 1.17 & 1.10 & 1.29 & 4.24 \\
Total Manure [P] (kg) & $\mathbf{5 6 7 . 9}$ & $\mathbf{1 6 8 . 7}$ & $\mathbf{3 0 4 . 7}$ & $\mathbf{3 6 5 . 0}$ & $\mathbf{1 , 1 5 3 . 8}$ \\
\hline
\end{tabular}


Raw Data for Calculating Average Hay Production

\begin{tabular}{lccccc}
\hline & \multicolumn{3}{c}{ Farms } \\
\cline { 2 - 6 } & \multicolumn{3}{c}{ Basic } & \multicolumn{3}{c}{ Complex } \\
\cline { 2 - 6 } Hay Production Acres & F1 & F2 & F3 & F4 & F5 \\
\cline { 2 - 6 } Weighted Average Production & 33.9 & 32.3 & 9.3 & 36.3 & 11.4 \\
Total Hay Production (tons) & 2.3 & 2.5 & 2.5 & 2.6 & 2.0 \\
Total Hay Production (lbs) & 78.3 & 80.3 & 23.3 & 94.6 & 23.1 \\
Hay \% DM & 156,618 & 160,592 & 46,500 & 189,210 & 46,112 \\
Hay \% P & 0.858 & 0.87 & 0.838 & 0.75 & 0.834 \\
Total Removal P & 0.0031 & 0.0028 & 0.0019 & 0.0022 & 0.0031 \\
Removal lbs P/ acre & 416.6 & 391.2 & 74.0 & 312.2 & 119.2 \\
Removal kg P/ ha & $\mathbf{1 2 . 3}$ & $\mathbf{1 2 . 1}$ & $\mathbf{8 . 0}$ & $\mathbf{8 . 6}$ & $\mathbf{1 0 . 5}$ \\
\hline
\end{tabular}


Appendix K: Equations and Conversions 
1. Weighted Average for calculating average hay crop removal

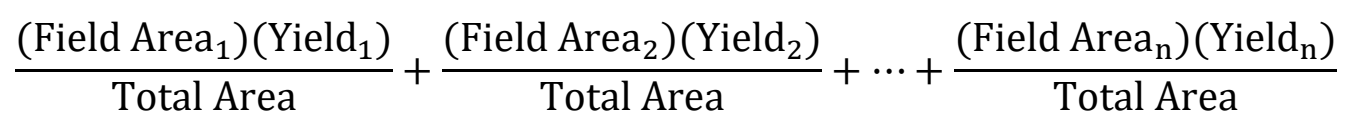

2. Percent difference for imported net $\mathbf{P}$ and manure collected $\mathbf{P}$

$$
\frac{(\text { Measured Manure } \mathrm{P}-\mathrm{Net} \mathrm{P})}{\text { Net } \mathrm{P}} * 100
$$

3. Percent difference for book value manure $\mathbf{P}$ and analyzed value manure $\mathbf{P}$

$$
\frac{\text { Manure }_{\text {Analysis P }}-\text { Manure }_{\text {Book Value P }}}{\text { Manure }_{\text {Book Value P }}} * 100
$$

4. P205 to $\mathbf{P}$

1 pound $\mathrm{P}_{2} \mathrm{O}_{5}=0.4364$ pounds $\mathrm{P}$

5. Pounds to Kilograms

1 pound $=0.4536$ kilograms

6. Acres to Hectares

$$
1 \text { acre }=0.4047 \text { hectares }
$$

7. Tons to Metric Tons

$$
1 \text { ton }=0.9072 \text { metric tons }
$$


Appendix L: Raw Data for Book Value and Analysis Comparison 
Raw Data for Manure Book Value and Analysis of Phosphorus Comparison

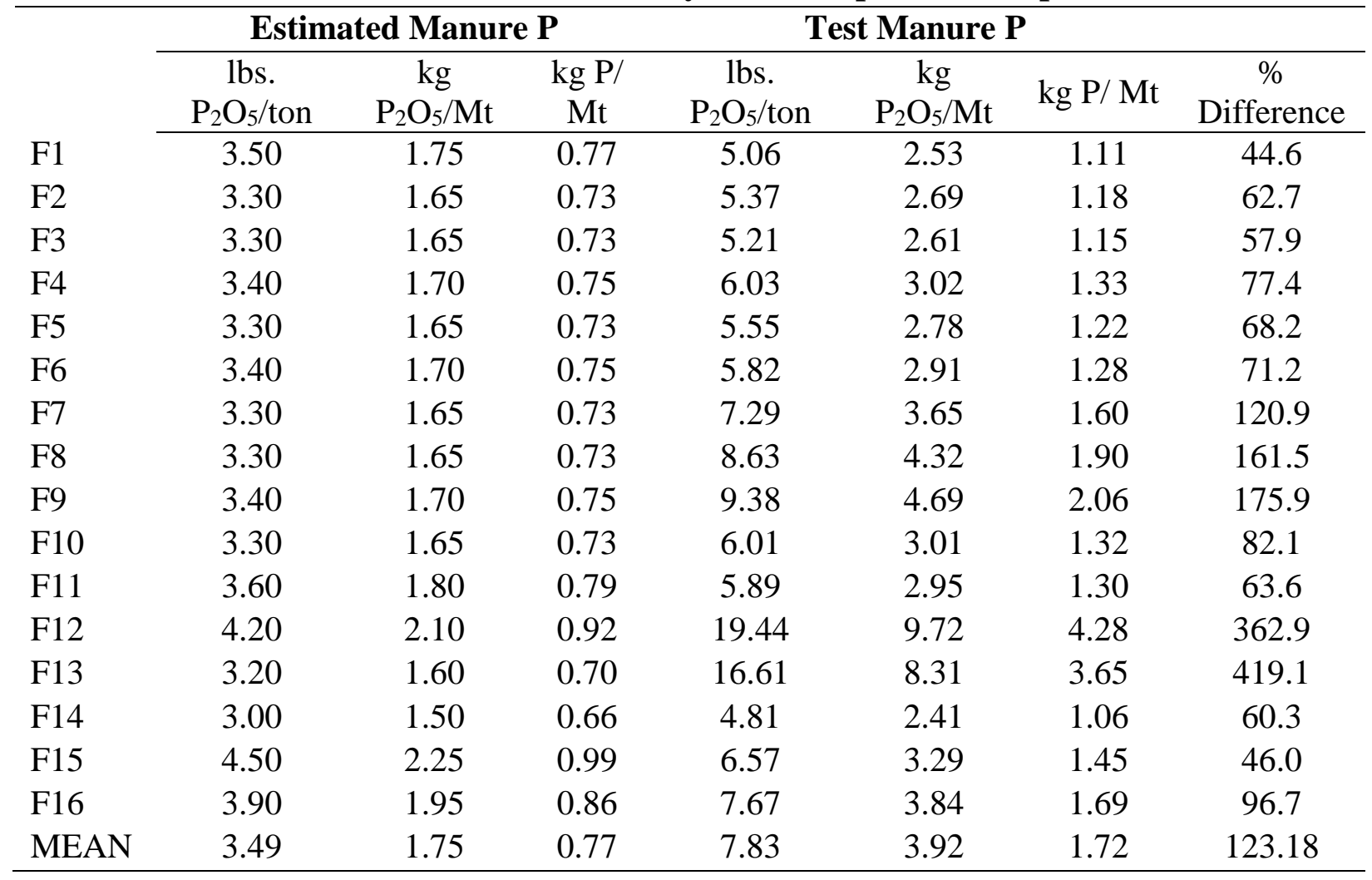


Appendix M: WV Hay Equivalency AU/ha 
WV statistics from 215 indicate an average hay yield 1.75 tons per acre with the majority of hay harvested in June. Based on this data, $66 \%$ of hay is removed and the resulting $34 \%$ of growth yields a total average land production of 2.65 tons/acre/year.

Based on animal needs of 2\% dry matter/day on a body weight basis, for a 1,200-pound cow, it requires $28 \mathrm{lbs} /$ hay/day or 5.1 tons of hay equivalency/year. Based on 2.65 tons of production/acre, density should be $0.52 \mathrm{AU} /$ acre or

$1.75 / 0.66=2.65$ tons/acre/year

$0.02 * 1,200=24 \mathrm{lbs}$. DM/Day

$24 / 0.85=28$ lbs. hay/day

$28 * 365 / 2000=5.11$ tons hay/year

$2.65 / 5.11=0.52 \mathrm{AU} / \mathrm{acre}$

$0.52 / 0.4047=1.28 \mathrm{AU} / \mathrm{ha}$ 
Appendix N: Theoretical Phosphorus Capture and Field Nutrient Balance 
Differences in Net Phosphorus and Collected Manure Phosphorus

\begin{tabular}{lcccccc}
\hline & & Basic & \multicolumn{4}{c}{ Complex } \\
\hline Characteristics & F1 & F2 & F3 & F4 & F5 & Mean \\
\hline Net Phosphorus (kg P) & 174.0 & 75.2 & 102.0 & 283.0 & 943.1 & 315.4 \\
$\quad$ Spreadable ha & 12.7 & 13.1 & 3.8 & 14.9 & 4.6 & 13.7 \\
$\quad$ Theoretical Application (kg P/ ha) & 13.7 & 5.7 & 26.8 & 19.0 & 205.0 & 54.1 \\
& & & & & & \\
Manure P (kg P/Mt) & 1.14 & 1.17 & 1.10 & 1.29 & 4.24 & 1.79 \\
Collected Manure (Mt) & 226.8 & 65.3 & 125.2 & 128.8 & 123.4 & 133.9 \\
Total Manure P (kg P) & 257.6 & 76.5 & 138.2 & 165.6 & 523.3 & 232.2 \\
Actual Application (kg P/ ha) & 20.3 & 5.9 & 7.4 & 11.1 & 113.8 & 37.5 \\
& & & & & & \\
\% Difference & 48.0 & 1.8 & 35.6 & -41.5 & -44.5 & 28.7 \\
\hline
\end{tabular}

Field Nutrient Balance on an Annual Basis

\begin{tabular}{|c|c|c|c|c|c|c|}
\hline & \multicolumn{3}{|c|}{ Basic } & \multicolumn{2}{|c|}{ Complex } & \multirow{2}{*}{ Mean } \\
\hline & F1 & F2 & F3 & F4 & F5 & \\
\hline & \multicolumn{6}{|c|}{ 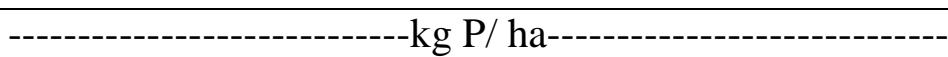 } \\
\hline Applied Manure & 20.3 & 5.9 & 7.4 & 11.1 & 113.8 & 31.7 \\
\hline Crop Removed (annually) & 9.1 & 9.0 & 5.9 & 6.4 & 11.7 & 8.4 \\
\hline Field Nutrient Balance & 11.2 & -3.1 & 1.5 & 4.7 & 102.0 & 23.3 \\
\hline
\end{tabular}

